\title{
The Impact of a Computerized Cognitive Training on Healthy Older Adults: A Systematic Review Focused on Processing Speed and Attention
}

\author{
Annette Shamala Arokiaraj, Rozainee Khairudin, Wan Shahrazad Wan \\ Sulaiman
}

To Link this Article: http://dx.doi.org/10.6007/IJARBSS/v10-i11/7647

DOI:10.6007/IJARBSS/v10-i11/7647

Received: 06 September 2020, Revised: 20 September 2020, Accepted: 17 October 2020

Published Online: 24 November 2020

In-Text Citation: (Arokiaraj, Khairudin, \& Sulaiman, 2020)

To Cite this Article: Arokiaraj, A. S., Khairudin, R., \& Sulaiman, W. S. W. (2020). The Impact of a Computerized Cognitive Training on Healthy Older Adults: A Systematic Review Focused on Processing Speed and Attention. International Journal of Academic Research in Business and Social Sciences. 10(11), 645-685.

\section{Copyright: (c) 2020 The Author(s)}

Published by Human Resource Management Academic Research Society (www.hrmars.com) This article is published under the Creative Commons Attribution (CC BY 4.0) license. Anyone may reproduce, distribute, translate and create derivative works of this article (for both commercial and non-commercial purposes), subject to full attribution to the original publication and authors. The full terms of this license may be seen at: http://creativecommons.org/licences/by/4.0/legalcode

Vol. 10, No. 11, 2020, Pg. 645 - 685

Full Terms \& Conditions of access and use can be found at http://hrmars.com/index.php/pages/detail/publication-ethics 


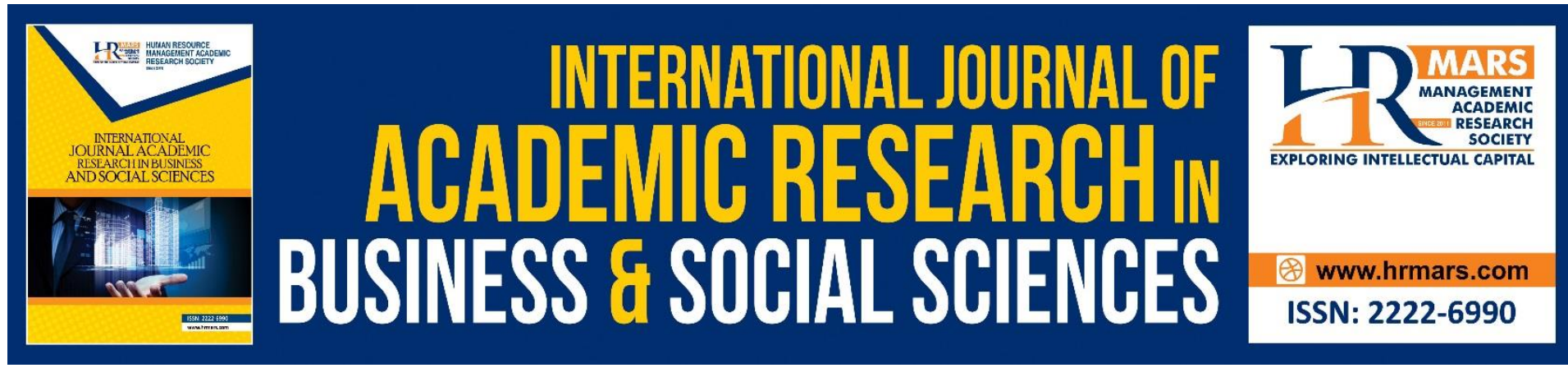

\title{
The Impact of a Computerized Cognitive Training on Healthy Older Adults: A Systematic Review Focused on Processing Speed and Attention
}

\section{Annette Shamala Arokiaraj, Rozainee Khairudin, Wan Shahrazad Wan Sulaiman}

Centre for Research in Psychology and Human Well-Being, Faculty of Social Sciences and Humanities, National University of Malaysia, 43600 UKM Bangi, Selangor, Malaysia.

Email: p106157@siswa.ukm.edu.my, rozaineekhai@ukm.edu.my, shara@ukm.edu.my

\begin{abstract}
As the world around us evolves into one with an aging population, it is essential to consider various strategies to reduce challenges encountered by older adults. Cognitive declination can be diminished through computerized cognitive interventions that employ frameworks of neuroplasticity to improve specific cognitive abilities. The speed of processing Brain HQ training by Posit Science Corporation has been frequently utilized for research purposes but its sole clinical validation of literature has yet to be reviewed. Therefore, the aim of this systematic review is to identify the benefits this training program confers to various cognitive abilities and everyday functions in addition to summarizing the similarities and differences across intervention characteristics. A search on a shared database of computerized cognitive training based research containing relevant studies from this program, PubMed and Google Scholar revealed a final list of 23 studies that were analyzed. Information obtained were segregated by benefits conferred to near transfer cognitive dimensions of processing speed and attentional domains, far transfers to other cognitive abilities and everyday functioning variables as well as intervention characteristics such as training exposure, adherence and implementation. Overall, most studies possessed low risk of bias and were of good quality. Small to large effect sizes were noted in near transfers to trained cognitive abilities while small to moderate effects sizes were observed in far transfers to untrained cognitive abilities and everyday functioning variables. Sufficient exposures at a laboratory, of four exercises and above, over a duration of 60 minutes or more per session and a total of more than 25 hours of training produces better effectiveness of the training program itself. Despite the presence of other biases in each individual research, current evidence supports the notion that Brain $\mathrm{HQ}$ is a clinically meaningful cognitive intervention that can promote healthy aging among older adults.
\end{abstract}

Keywords: Computerized Cognitive Training, Posit Science, Brain HQ, Speed of Processing, Older Adults. 


\section{Introduction}

The aging population worldwide is currently on the rise. World Population Prospects: the 2019 Revision revealed information that in 2019, every one in 11 people (9\%) would be over the age of 65 . However, this figure would almost double by 2050 as one in six people in the world would fall within that age category (16\%) (United Nations, 2020). Mafauzy (2000) mentioned that the percentage of individuals aged 60 and above in Malaysia has been on a significant rise, from $5.2 \%$ in 1970 , to $5.7 \%$ and $6.3 \%$ in 1990 and 2000 respectively. He also predicted that by 2020, the number of Malaysians aged 60 and above was estimated to be around 3.3 million. Confirming the above information, Hirschmann (2019) mentioned that at present, approximately 2.17 million (6.7\% of the total population) Malaysians were aged above 65 years old and the country would face the prospects of an aging population as early as 2030. It is rather interesting to note that a mere 20 years ago, the population of Malaysians aged 60 and above were estimated to be approximately half the amount at 1.4 million (Mafauzy, 2000).

All the above figures are a clear indication that current life expectancy, in Malaysia as well as other countries has increased, thus warranting studies on the aging population (Mafauzy, 2000; Szelag \& Skolimowska, 2012). An overall decline in quality of life on each elderly individual is bound to take place as the aging population increases, creating unique problems, unforeseen challenges and demands on the individual's themselves from a physical, emotional and cognitive perspective as well as on health care and social services systems (Jobe et al., 2001; Mafauzy, 2000).

It is a rare occasion that older adults would escape the great range of aging declination processes. Frail older adults may experience problems such as urinary incontinence, instability, falls and acute confusion states, just to name a few challenges (Mafauzy, 2000). Gradual cognitive decline is rather universal and falls within the category of normal aging processes (Edwards et al., 2013b; Wolinsky et al., 2011). It causes cognitive deficits in the individual such as declines in memory, attention, working memory and speed of processing (Szelag \& Skolimowska, 2012; Zelinski et al., 2011). These processes would not only compromise an individual's capacity to complete everyday tasks efficiently, but also reduce their ability to learn other cognitive processes and increase their risk of losing independence, as cognition plays a vital role in our day to day functioning, which includes managing ourselves, activities and finances. There is also an increased chance of being diagnosed with a neurodegenerative disorder such as dementia or Alzheimer's disease on a worst case scenario (Acevedo \& Loewenstein, 2007; Simpson et al., 2012; Zelinski et al., 2014).

Circumstances such as the above have left an essential need to identify efficient and effective cognitive training interventions for older adults to delay the aging process and enable older adults to cope better during this phase of life (ten Brinke et al., 2017; Sharpe et al., 2014a; Smith et al., 2009; Wolinsky et al., 2011). Although Malaysia has a rather comprehensive range of medical and healthcare services, there is a lack of special programs to smoothen this transition for the aged population due to a lack of priority and personnel in the geriatric field (Mafauzy, 2000).

Much information has been made available to reduce age related functional declines (Castells-Sanchez et al., 2019). However, few studies have been conducted to validate if improving cognitive functions would lead to either short-or-long term effects on an individual 
in terms of improving their ability to function and live independently (Ball et al., 2002). The solution to the above problem resides in understanding the underlying idea of the brain. Neuroplasticity can be defined as long lasting changes that occur in neural connections when we learn new things (Chudler, n.d.). The neuroplasticity of the brain functions in the same way physical training may be used to improve physical abilities in an individual. Therefore, due to its plasticity, the brain provides a life-long capacity and opportunity for humans to reverse or slow down the aging process through the induction of neural changes in the brain, via cognitive training to strengthen their cognitive abilities. This is especially beneficial when training periods are well organized and intensive practice of the new skills are enabled to ensure learning and retention to the highest possibilities. With a well-designed cognitive training program that targets improvement in cognitive functions of an individual, the dimensions of negative reorganization would at least be partially transformed to promote positive brain plasticity and a better quality of life among older adults (Mahncke et al., 2006; Pauwels et al., 2018; ten Brinke et al., 2017; Wolinsky et al., 2013).

Computerized cognitive training (CCT) is used to enhance cognition or cognitive skills of individuals who utilized the strategy. CCTs are cognitive interventions on an individual electronic platform, such as a computer, laptop or tablet that requires a physical response (i.e a button press). It is a performance based approach that promotes ease of use, great accessibility and is certainly cost effective in this digital era we live in. A range of CCT programs such as Brain HQ, Lumosity, My Brain Trainner, Brain Age 2 and many other have been developed for a similar purpose, to help to delay the cognitive decline process (Blackwood et al., 2016; Fitzgerald, 2017; ten Brinke et al., 2017).

As beneficial as it is, there are presence of some inconsistencies in the evidence related to the transfer of the training gains to everyday functioning. As an example, many large trials that have focused on the speed of processing (SOP) training discovered that there were some longterm effects of the training that was visible and enduring on participant's daily activities, however, no immediate transfer to other cognitive tests were visible (Eramudugolla et al., 2017; Zelinsky et al., 2011; Zelinsky et al., 2014). Griffith-Greene (2015) in a research by Marketplace in collaboration with the chairperson of the Cognitive Neuroscience and Imaging branch at the Brain and Mind Institute at Western University, Canada suggested no significant improvements across memory, reasoning, concentration and planning in participants who underwent a CCT over a short training period of 15 minutes or more, three times a week for two and a half and four weeks. Some cognitive neurologists argue that there is not much evidence suggesting that CCTs help to delay cognitive decline (Fitzgerald, 2017). Similarly, Simmons et al. (2016) reported that there are "limited and inconsistent" evidence to support the notion that CCTs can be used for a similar purpose as described above.

Nevertheless, the impact of these CCTs in enhancing specific domains of cognitive abilities are rather impressive can be seen across some of the articles reviewed later. Several follow-up studies of The Advanced Cognitive Training for Independent and Vital Elderly (ACTIVE) trial, which utilized three CCTs to enhance memory, reasoning and speed of processing in healthy older adults, showed strong transfer to the cognitive abilities on trained tasks and some transfers to other cognitive abilities than the one trained for as well as everyday functioning, which will be described in greater detail later in this article (Ball et al., 2002; Ball et al., 2010; Jones et al., 2013; Rebok et al., 2014; Sharpe et al., 2014a, 2014b; Tennstedt \& Unverzagt, 
2013; Willis et al., 2006). Fitzgerald (2017) specifically mentioned that participants who received the SOP training used in this trial (which was developed by Posit Science Corporation), were "less likely to have dementia". Rebok, G. and Knopmann D.S. made several statements suggesting the possibility that CCTs may have lasting benefits and arguments on both ends of the spectrum are visible. These experts also highlighted the need for more substantial research to be conducted to test out these claims (Fitzgerald, 2017).

Brain HQ by Posit Science Corporation (San Francisco, California, USA) is an interactive brain training program that was developed by a team of top neuroscientists. It includes various exercises targeted to improve cognitive abilities such as attention, auditory processing, navigation, memory, speed of processing, people skills, visual processing and a few others. More than a 100 journal articles that report the impact of the Posit Science Brain HQ exercises have been published in peer reviewed journals. This program is currently available in 9 different languages (Posit Science, 2020).

The most utilized training is the SOP training program which was an adaptation from Ball and Roenker's visual SOP training in 2007. All tasks were maintained and modified to be selfadministrative and user friendly, gaming elements were added to improve user engagement and increase compliance (Wolinsky et al., 2011). As many of the Posit Science's scientists are experts in brain plasticity, their exercises are designed to bring about changes in the brain. Trainings include a core focus on improving speed to meet real-world requirements, with an increasing intensity across accuracy, whilst maintaining its continuous adaptability to each individual's performance on relevant exercises. Exercises are designed in an attractive way that stimulates neurotransmitters and keeps individuals engaged via increasing their intention to continually participate in the program and gradually generalizing to real-world experiences (Posit Science, 2020).

The aim of the SOP training is to improve the sensory search speed of an individual, be it visual, auditory or both, and their ability to perform one or more attentional tasks quickly. Using an electronic platform, participants are trained by gradually reducing the stimulus duration on information processing tasks as it becomes more challenging. Most speed of processing training begins with the introduction of the simplest tasks which then increases in complexity to fully developed this cognitive ability in the individual. Interventions such as CCTs are designed to extend independence and dignity of older adults (Ball et al., 2002; Edwards et al., 2002; Jobe et al., 2001).

As mentioned previously, a random search outcome on the worldwide web would reveal a great deal of brain training interventions to improve its functionality. Posit Science's Brain HQ program has the highest level of empirical evidence with regards to the effectiveness of the exercises involved in improving a range of cognitive abilities (Posit Science, 2020). Many systematic reviews and meta-analysis have been published comparing various cognitive interventions and their effectiveness (Marusic et al., 2018; Nguyen et al., 2019; Sprague et al., 2019) Some were focused specifically on systematically reviewing CCTs (Kua et al., 2018; Shah et al., 2017; Sood et al., 2019). To the knowledge of the researcher, there has been no systematic review that solely focusses on analysing the training provided specifically by the Posit Science Corporation only, confirming novelty of this review. Therefore, the aim of this systematic review was to examine researches that have utilized specifically the SOP training 
developed by Posit Science to provide a thorough analysis of the particular program. The objectives that would be addressed in this review are:

- To identify benefits of the SOP training conferred to processing speed and attentional cognitive domains;

- To summarize similarities and differences across exposure, adherence and implementation of the SOP cognitive intervention according to their outcomes.

- To identify how many studies included transfers of the SOP training and which of these have conferred benefits to cognitive abilities and everyday functions.

\section{Methodology}

This systematic review was conducted in a series of five steps identified by Sood et al. (2019). These five steps include: 1 . Identifying the research question; 2 . Identifying relevant studies; 3. Screening or study selection, 4. Charting and extraction of data; and 5. Study synthesis, collating, summarizing and reporting the results. Guidelines provided by the Preferred Reporting Items for Systematic Reviews and Meta-Analysis (PRISMA) were used to ensure high quality and consistency of the review itself (PRISMA Group, 2020; Sood et al., 2019).

Identifying the Research Question The three research questions that would be addressed in this systematic review are:

1. Is Posit Science's speed of processing training more effective than other strategies and controls in improving processing speed and/or attentional cognitive domains?

2. How does exposure, adherence and implementation of Posit Science's speed of processing training affect its effectiveness on improving this cognitive ability?

3. Does Posit Science's speed of processing training impact transfers to other cognitive abilities and everyday functions?

Identifying Relevant Studies The search process for this study was carried out beginning $18^{\text {th }}$ March 2020 and completed on $3^{\text {rd }}$ June 2020. Three sources of information were used to gather data for this research, namely, a shared database of studies involving CCTs, PubMed and Google Scholar. The PICO framework was used to determine the eligibility criteria of research that would be included in this systematic review. Its abbreviation indicates " $P$ " for Population, "I" for Intervention, " $\mathrm{C}$ " for Comparison and "O" for Outcome (Methley et al., 2014). The PICO for this systematic review is mentioned below:

- $\mathrm{P}$ (Population) - Healthy older adults

- I (Intervention) - Speed of processing training by Posit Science

- C (Comparison) - Experimental vs. control groups

- O (Outcome) - Processing speed, attention, other cognitive abilities and everyday functions

The search was initiated by scouting for articles on a shared database with all research that has been conducted on CCTs obtained from an employee at Posit Science Corporation. Using the tags "Posit Science" and "trials", the researchers were able to access all published articles that utilized training programs owned by the corporation. These articles were further screened to select specific researches that have utilized the SOP training program by Posit Science. 
The articles obtained through this database search were cross referenced and checked using PubMed and Google Scholar in addition to conducting a search on these databases. The search strategy used on PubMed is as follows. Some search terms or key words used include: older adults, cognitive training, computerized cognitive training, cognitive intervention, computerized cognitive intervention, brain games, brain fitness, brain training, Brain $\mathrm{HQ}$, Posit Science, InSight, speed of processing, processing speed. Initially, the term "healthy older adults" was included in the above list. However, it was later removed because definition of the term "healthy" seems to vary greatly from one study to another. Therefore, this element was screened across all reviewed articles on a case to case basis on the inclusion criteria of a healthy older adult, defined generally as someone who is cognitively intact (with a Mini Mental State Examination (MMSE) score of 23 and above or equivalent for other measures of the same nature), without clinical diagnosis of mild cognitive impairment or other clinicalbased population and lacked major cognitive, psychological, neurological and/or sensory impairments.

A total of 32 possible combinations of search categories, using the keywords above, led to the compilation of related manuscripts. Using the advanced search option, a minimum 3 and maximum 4 search criteria with the Boolean Phrase "AND" was used each time a search was conducted. An example of a search with 3 and 4 criteria respectively are as follows: "Brain HQ" AND "speed of processing" AND "older adults" (3 criteria), "computerized cognitive intervention" AND "Posit Science" AND "processing speed" AND "older adults". Each concept was searched across all fields. Search results were limited to articles published in the English language, as the author did not have professional resources to translate articles published in other languages, as well as to avoid possible bias and misinterpretation from informal translations, among other concerns.

Screening and Study Selection Inclusion criteria of this study were: (a) usage of Posit Science's SOP training as part of the research; (b) participants aged 55 and above; (c) inclusion of human subjects only; (d) healthy participants (as defined in the previous section); (e) peer reviewed reports of clinical trials evaluating the effects of Posit Science's SOP CCT on formal outcome measures or specific cognitive domains; $(f)$ a research with reported posttest results (not a protocol paper); (g) includes a control group of some sort (i.e active - educational training/non-cognitive training or passive - wait-list/no contact); and (h) if several manuscripts using data from the Advanced Cognitive Training for Independent and Vital Elderly (ACTIVE) trial came up in the search results, they were all included for full evaluation (Ball et al., 2002; Rebok et al., 2014; Willis et al., 2006).

Exclusion criteria of this research were: (a) no results from other CCT's in the SOP dimension were analyzed or used as comparisons; (b) studies of populations other than healthy older adults, such as those that include participants with impairments, ailments, mental health issues or deficits in initial baseline measurements; (c) conference papers; (d) review abstracts; (e) other review articles; and ( $f$ ) studies without cognition and everyday functioning related variables as measures.

Outcome measures included in the selection criteria were: for primary outcomes the criteria included (a) cognitive function/abilities measured using standardized measures for SOP and Attention; (b) Intervention specifications measured by exposure (duration per session, 
frequency and total hours of contact); (c) implementation (lab or home based; number of activities completed) and adherence (attrition rates and reasons for attrition); (d) effectiveness of CCT, measured through effect sizes (if available) and other results. For secondary outcomes the criteria included adaptive functioning through far or near transfer measured by effect sizes (if available) and other results.

A comprehensive two-level eligibility process was used to identify studies that would be included in this systematic review. The first level involved screening of articles via titles and abstracts. The second level involved screening of available full texts.

Charting and Extraction of Data Reviewer independently screened articles by title and abstracts along with the relevant websites to identify eligible articles. Full text records were also viewed for further screening prior to deciding inclusion of an article in this review. Most articles obtained from the shared database provided by the Posit Science employee included full text articles. Non-full text articles that were deemed relevant through title and abstract screening were searched via Google Scholar as a first step. In situations where these manuscripts could not be obtained, specific requests were channeled to the principal investigator of each study. Some manuscripts have been received while other are pending receipt. In articles containing information on both the pilot and main study, only results of the latter were utilized for the purpose of this review. Extracted data were charted on Microsoft Word using the template in the study synthesis section.

Risk of Bias in Individual Studies Once the final selection of studies to be included in this review was completed, the author assessed risk of bias of each individual study using the Cochrane's Risk of Bias Tool. This assessment was done at a study level across all seven components to account for any heterogeneity of results: random sequence generation, allocation concealment, selective reporting, other bias, blinding participants and personnel, blinding of outcome assessment and incomplete outcome data. Results from this analysis were converted into Agency for Healthcare Research and Quality (AHRQ) standards by utilizing the relevant thresholds provided. The characteristics of these thresholds are:

- Good quality: All criteria met (i.e. low for each domain)

- Fair quality: One criterion not met (i.e. high risk of bias for one domain) or two criteria unclear, and the assessment that this was unlikely to have biased the outcome, and there is no known important limitation that could invalidate the results

- Poor quality: One criterion not met (i.e. high risk of bias for one domain) or two criteria unclear, and the assessment that this was likely to have biased the outcome, and there are important limitations that could invalidate the results

- Poor quality: Two or more criteria listed as high or unclear risk of bias

Study synthesis. The following data was extracted onto a template: study source, sample size, age, intervention duration, frequency, intensity, number of exercises utilized, venue, control conditions with main study outcomes at post-intervention and follow-ups. Author included

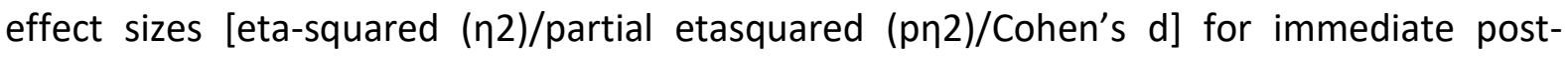
intervention data including the cognitive outcome measures of processing speed and attention. For studies that did not report effect sizes, other relevant information on performance on a measure after training that could be used as an indication of effectiveness 
was reported. Near and far transfer to other cognitive abilities and everyday functions were reported across studies in which the said data were available.

\section{Results}

Figure 1 illustrates the flow of studies into this systematic review. A total of 355 articles were identified across the shared database, PubMed database and Google Scholar search engine. 208 articles were retrieved after removing duplicates. 171 articles were excluded for the following reasons: different category of participants i.e children, adolescents, young adults, veterans, etc.; participants that are not healthy, i.e stroke, dementia, Parkinson's, schizophrenia etc.; articles not related to area of research interest; non-Posit science training; non-research based articles; non-full text articles; articles requested but not received; and interim analyses. Upon exclusion of the above, 37 full text articles were identified and assessed for eligibility. The final analysis was performed on 23 articles that fit the inclusion/exclusion criteria mentioned in the previous section.

Analysis of Risk of Bias in Individual Studies. 15 studies were categorized as good quality studies by AHRQ standards as each reported low risk of bias across all seven domains. Five studies were classified as fair quality as most of the domains were low risk, but two domains were classified as unclear. Three studies were classified as poor quality. O'Brien et al (2013) rated unclear across four of the domains namely, random sequence generation, allocation concealment, other bias and blinding of outcome assessment. Eramudugolla et al (2017) was rated unclear across the domain of blinding outcome assessment and high risk of bias across three domains namely, random sequence generation, allocation concealment and other bias. Edwards et al (2002) rated unclear across three domains namely, allocation concealment, other bias and blinding of outcome assessment. Table 1 in the Appendices lists further details the specifications accordingly.

Study Characteristics Summary. Study characteristics, intervention features and cognitive outcomes are summarized in Table 2 of the Appendices. A total of eight studies involved the participant database from the ACTIVE trial, three studies used the participant database from the IMPACT trial and the remaining 12 studies were independent researches.

Adherence Rates. Adherence rates, from studies where this information was made available, were not significantly different between TGs and CGs (Faust et al., 2020; Smith et al., 2009). Adherence rates ranged from moderate to high for studies used in this review. Smith et al (2009) reported a participant retention rate of $92.1 \%$ for the TG and 86.9 for the AC. In using part of the ACTIVE trial participant data, Jobe et al (2001) as mentioned in Sharpe et al. (2014a) at a 1-year assessment reported 98.7\%, Willis et al (2006) at a 5-year assessment reported $67 \%$ and Rebok et al. (2014) at a 10 -year assessment reported $44 \%$ adherence rates respectively. In another study by Faust et al (2020) where participants were required to complete between 30 to 40 hours of training, only $3.5 \%$ completed less than 30 hours.

Reasons for Non-Adherence Some common reasons for non-adherence across the studies include training non-adherence, voluntarily withdrawals, (Rebok et al., 2014; Sharpe et al., 2014a; Smith et al., 2009), investigator drop for inclusion or exclusion reasons such as more health problems, lower cognitive function or incompletion of assessments (Sharpe et al., 2014a; Smith et al., 2009; Willis et al., 2006), lost to follow-up (Smith et al., 2009), or death 
(Rebok et al., 2014; Sharpe et al., 2014a; Smith et al., 2009). It was also found that participants who were older, male and less educated and were less likely to be retained at 5 years (Willis et al., 2006).

\section{Intervention Features}

Duration Per Training Session. The duration spent on per training session differs greatly between all studies. The longest training duration per session, a total of 90 minutes, was reported by (Belchior et al., 2013). This was followed closely by a total of 7 studies reporting overall durations of within 60 to 75 minutes for each session (Ball et al., 2002; Jones et al., 2013; Rebok et al., 2014; Sharpe et al., 2014a, 2014b; Tennstedt \& Unverzagt, 2013; Willis et al., 2006). Majority of studies in this review reported a time frame of 60 minutes per session (Anderson et al., 2014; Anderson et al., 2013; Belchior et al., 2019; Edwards et al., 2002; Edwards et al., 2013a; Mahncke et al., 2006; Smith et al., 2009; Zelinski et al., 2011; Zelinski et al., 2014). Two studies reported a total of 70 minutes per session (Ball et al., 2010; O'Brien et al., 2013). Smith et al (2018) mentioned that participants underwent a period of between 50 to 60 minutes of training each time. The shortest duration was reported in two studies, a total of 40 minutes per session, compared to other studies in this review (Faust et al., 2020; Mishra et al., 2015).

Although Faust et al (2020) reported the shortest training duration per session, a small to moderate sized significant effect was displayed by the visual SOP training group and significant pre-post changes was displayed by the auditory SOP training group and control group in processing speed. The combination of visual and auditory SOP training group did not produce significant pre-post outcome measure changes. Ironically, Belchior et al (2013) that reported the longest training duration per session displayed results with improvements in scores across SOP training group from pre-test to post-test compared to other training and control groups, however none of these results were significant. All studies within the 60 to 75 minutes and 60 minutes duration per training session showed improvements (some significant) in processing speed with effect sizes ranging from moderate to high. O'Brien et al (2013) which included training of 70 minutes per session reported significant improvements across attentional domains in SOP training group compared to the control group. However, only small to moderate effect sizes in processing speed were noted in Smith et al (2018) which included 50 to 60 minutes training per session. Specific information with regard to results of each study is detailed in Table 2.

Total Training Hours. Categorization of this element was divided into two. The first involves studies that reported total training duration below 25 hours. Belchior et al (2013) reported a total of 9 training hours while Edwards et al (2002); Eramudugolla et al (2017) and Mishra et al (2015) reported a total of 10 training hours. Participants in the Edwards et al (2002) study needed to complete a minimum of 8 hours of training in total to be included into the results analysis. Both Edwards et al (2002); Mishra et al (2015) reported significantly better performance on processing speed measures. The average amount of hours of training completed by participants in Eramudugolla et al. (2017) was 7.9 hours and results showed better performance and a moderate effect size on processing speed measures. However, no transfer effects were noted on attentional domains. Belchior et al (2013) reported nonsignificant but slight improvement in processing speed and attentional domains. Participants in the Faust et al (2020) study completed 15 hours of training. Smith et al (2018) designed a 
study that included a total of 18 hours in training, 10 of which was dedicated to the initial training sessions, and four hours for each booster session (it included two booster sessions). Participants in this study completed an average of 8.9 hours in training. Both O'Brien et al (2013); Edwards et al (2013a) reported that participants had to complete 20 hours of total training. Participants in the SOP training group of the Edwards et al (2013a) study were mentioned to have completed 15 hours of total training on average. Edwards et al (2013a) reported significantly greater improvement in speed of processing measure scores. Results from Faust et al (2020); O'Brien et al (2013); Smith et al (2018) are similar to the information mentioned in the previous section.

Another group of studies that fall within the range of the above category are the ones reporting findings from the ACTIVE Trial. Studies that were part of the ACTIVE trial that did not include participants that were not involved in the booster training reported a total of within 10 to 12.5 hours of training (Jones et al., 2013; Sharpe et al., 2014a, 2014b). In these studies, improvement of performance on speed of processing was reported with moderate effect sizes. Another study by Ball et al (2010) that analysed results from the ACTIVE trial database and did not include participants that were booster trained involved 11.6 hours of total training, and as long as participants in this study completed a minimum of 9 training sessions (approximately 10.5 hours) they were included in the results analysis. Ball et al (2002) however included participants from the initial and the first booster training in their analysis, resulting in total training within the range of 15 to 17.5 hours. Results from this study indicated large effect sizes on speed of processing performance all participants. Those who received booster training performed even better than those who didn't and control group participants. Three other studies that fall within the range of 10 to 22.5 total hours of training were those involved in the ACTIVE trial which included database of participants who had completed only the initial training (10 to 12.5 hours), the initial and first booster trainings (15 to 17.5 hours) and the initial training in addition to the first and second booster training (20 to 22.5 hours) (Rebok et al., 2014; Tennstedt \& Unverzagt, 2013; Willis et al., 2006). Results of these studies reported significantly improved performance on speed of processing measures with moderate to large effect sizes. Once again, booster trained participants outperformed all other groups.

The second category includes all studies that reported a total of 25 or more training hours. Three studies that were part of The Improvement in Memory with Plasticity- based Adaptive Cognitive Training (IMPACT) trial reported a total of 40 training hours (Smith et al., 2009; Zelinski et al., 2011; Zelinski et al., 2014). The IMPACT trial studies reported large effect size on processing speed measures but small effect sizes on attention measure. Two studies by Anderson et al (2013); Anderson et al (2014) reported a total of 40 training hours as well. These studies reported improvement in speed of processing from pre-to-follow-up studies. Another study by Mahncke et al (2006) mentioned that participants completed between 40 to 50 hours of training in total. This study reported large improvements in processing speed with a moderate effect size on the measure. Lastly, the highest amount of total training hours in a study by Belchior et al. (2019) where participants were required to complete 60 hours but the SOP training group completed 66.2 hours of training on average. In this study, moderate to large effect sizes were seen on processing speed and large effect sizes were seen on attentional domains. Table 2 presents detailed information of the results from each study. 
Number of Exercises Each research used varying number of exercises in the SOP training. Eramudugolla et al (2017); Mishra et al (2015); Smith et al (2018) only used one exercise. Results from these studies showed improvements in speed of processing but at a small to moderate effect size range and no transfers to attentional domains. All the ACTIVE trial studies (Ball et al., 2002; Ball et al., 2010; Jones et al., 2013; Rebok et al., 2014; Sharpe et al., 2014a, 2014b; Tennstedt \& Unverzagt, 2013; Willis et al., 2006); Belchior et al (2013) used a total of four exercises as part of the SOP training program. Similar to the above sections, the ACTIVE studies reported significantly improved performance on speed of processing measures with moderate to large effect sizes. Once again, booster trained participants outperformed all other groups while Belchior et al (2013) reported non-significant but slight improvement in processing speed and attentional domains.

Belchior et al (2019); Edwards et al (2002); Edwards et al (2013a); O’Brien et al (2013) utilized five exercises in their respective training programs. The IMPACT trial studies Smith et al (2009); Zelinski et al (2011); Zelinski et al (2014); Mahncke et al (2006), Anderson et al (2013), Anderson et al (2014) used six exercises in their SOP training programs. Faust et al (2020) utilized the most amount of exercises from Brain HQ by Posit Science in their SOP training, a total of within five to six exercises in each training group as they studied SOP from a visual, auditory and a combination of visual and auditory perspectives. Information on the mixed results of these studies can be referred to in previous sections or from Table 2.

Venue of Implementation Majority of the studies reviewed in this research had conducted SOP training at a laboratory. Amongst these, most reported improvements across processing speed scores post-training, with moderate to large effect sizes (Ball et al., 2002; Ball et al., 2010; Belchior et al., 2013; Edward et al., 2002; Edward et al., 2013a; Jones et al., 2013; O’Brien et al., 2013; Rebok et al., 2014; Sharpe et al., 2014a, 2014b; Tennstedt \& Unverzagt, 2013; Willis et al., 2006) except Faust et al (2020) which reported improvements with small effect sizes in the measure.

Nine studies indulged in home-based training approaches with a majority reporting large (Smith et al., 2009; Zelinski et al., 2011; Zelinski et al., 2014) to moderate (Eramudugolla et al., 2017; Mahncke et al., 2006) effect sizes in measures of processing speed. Smith et al. (2018) was the only study in the home-based training category that reported a small effect size on the same measure. The other home-based training studies reported improvements in performance of processing speed in assessments at post-tests and follow-ups (Anderson et al., 2013; Anderson et al., 2014; Belchior et al., 2019).

Only Mishra et al. (2015) allowed a slightly different arrangement for training through which participants could select their preferred method of training delivery prior to the initialization of training sessions, such as participating in training at home or at a laboratory facility. Nevertheless, once participants have chosen their preferred locations, trainings were conducted only at that venue for the respective participant until completion. Results of this study showed some improvements in scores on processing speed measures at post-test. Details on significance and actual effect sizes are included in Table 2. 


\section{Overall Performance of Training Groups}

Across all researches reviewed, performances of groups that were exposed to SOP training were significantly much better compared to that of control group strategies Anderson et al (2014); Anderson et al (2013); Ball et al (2002); Ball et al (2010); Belchior et al (2013); Belchior et al (2019); Edwards et al (2013a); Edwards et al (2002); Eramudugolla et al (2017); Faust et al (2020); Jones et al (2013); Mahncke et al (2006); Mishra et al (2015); O'Brien et al (2013); Rebok et al (2014); Sharpe et al (2014a; 2014b); Smith et al (2018); Smith et al (2009); Tennstedt \& Unverzagt (2013); Willis et al (2006); Zelinski et al (2011); Zelinski et al (2014) with the comparative difference reported by Jones et al (2013) that despite the many advantageous effects of training on groups, age related change in CG showed slower decline compared to those in TGS in one of the ACTIVE trial based researches.

\section{Effect on Speed of Processing. Effect Sizes Summary}

Two studies showed small effect sizes (Faust et al., 2020; Smith et al., 2018). Jones et al (2013) displayed small to moderate effect sizes in the dimension. Eramudugolla et al (2017), Mahncke et al (2006); Rebok et al (2014) discovered moderate effect sizes on SOP measures. Ball et al (2002); Belchior et al (2019) (on the first booster session) reported moderate to large effect sizes on this cognitive ability. Large effect sizes in SOP measures were noted in (Ball et al., 2002; Smith et al., 2009; Willis et al., 2006; Zelinski et al., 2011). Other Results Summary. SOP training is a significant predictor of UFOV performance (Eramudugolla et al., 2017; Sharpe et al., 2014a, 2014b) and both mediation and direct effect of training on UFOV performance is significant (Ball et al., 2002; Edwards et al., 2013a; Edwards et al., 2002; Eramudugolla et al., 2017; Mishra et al., 2015; Sharpe et al., 2014a; Tennstedt \& Unverzagt, 2013). Some significant improvements were found at post-training and all follow-ups at 3 months (Belchior et al., 2019), 6 months (Anderson et al., 2014), $5^{\text {th }}$ year (Jones et al., 2013; Tennstedt \& Unverzagt, 2013; Willis et al., 2006) and $10^{\text {th }}$ year (Rebok et al., 2014). Some groups in the Faust et al (2020) study, namely visual processing speed and accuracy training, combination of video and audio processing speed and accuracy training and control group did not show significant improvements in the measure. However, Jones et al (2013) reported that age related change in control groups, showed a slower decline compared to those in the SOP training group. This study further mentioned that participants in the SOP training group performed at a level of about 7.6 years younger than their counterparts in the control group. In Belchior et al (2013), the SOP trained group produced not significant but marginally better performance on the UFOV test compared to the Medal of Honour Videogame group (TGV1) and placebo control (PCT). Table 2 presents further details on these results.

Effect on Attention Domains. Effect Sizes Summary. Smith et al. (2009) reported small effect sizes on attention related variables on Repeatable Battery for the Assessment of Neuropsychological Status (RBANS) Auditory Memory/Attention measure $(d=0.23)$. Belchior et al (2019) found moderate effect sizes on both multiple object tracking and attentional blink measure. For further clarifications, please refer to Table 2. Other Results Summary. O'Brien et al (2013) found that the SOP trained group in this study showed significant improvement in specific increase in allocation of attention through visual space during visual search and attentional capacity versus the control group which showed no significant improvement in the above mentioned areas. Belchior et al (2013) found that the trained group performed better in selective attention however Eramudugolla et al (2017); Zelinski et al (2011) found no significant impact of training on attention. In further describing the results from the 
previous section from Belchior et al (2019), videogame training group performed better in attentional blink post-training compared to the SOP training group however these results showed continued improvement in the SOP training group and not the videogame training group at the 3 month follow-ups. Although the SOP training group performed better than the videogame training group on multiple object tracking, the effect disappeared after 3 months.

Transfers to Cognitive Abilities. Memory SOP training helps to transfer an effect on overall memory (Zelinski et al., 2011), working memory by visual SOP training group not auditory SOP training group (Faust et al., 2020), auditory verbal learning and letter number sequencing (Zelinski et al., 2011) and verbal fluency (Belchior et al., 2013) at small effect sizes. Improvements in the training indicator of speed was associated with transfer to a relatively easy list memory outcome (Zelinski et al., 2014).

Transfers to Everyday Functions. Driving Across two studies, highest number of collisions and at-fault crashes reported among control group participants. Participants from TGS reported significantly lower rates of motor vehicle collisions (MVC's) per year of driving exposure or per person miles driven and only 18-at fault crashes (Ball et al., 2010) and were $40 \%$ less likely to cease driving 3 years after the 5 -year follow-up assessments (Tennstedt \& Unverzagt, 2013). Training also was proven to show significant reduction in completion speed and significant increase in response time for detecting hazards on the Maze Test and Hazard Perception Test, respectively (Eramudugolla et al., 2017). Everyday Speed and Everyday Problems. Significant improvements on Instrumental Activities of Daily Living (IADL) or Timed Instrumental Activities of Daily Living (TIADL) performances have been reported (Belchior et al., 2019) at small effect sizes (Edwards et al., 2002). Some research showed no improvements or significance in these measures (Ball et al., 2002; Belchior et al., 2019; Rebok et al. (2014); Willis et al., 2006). Booster training groups of participants seem to show significant impact on everyday problems task and everyday speed test (Tennstedt \& Unverzagt, 2013; Willis et al., 2006). Better performance on IADL or TIADL at the 3 months follow up with a rather small effect size was noted in the SOP training group compared to the control group (Belchior et al., 2019).

\section{Discussion}

This systematic review aimed to explore CCTs focused on SOP training specifically by Brain HQ of Posit Science Corporation. Benefits of the SOP training conferred to processing and attentional cognitive domains were evaluated across 23 studies. This review also intended to elucidate the SOP cognitive intervention outcomes with respect to various aspects of training namely exposure, adherence and implementation. In addition to the above, the study also explored transfer effects the training had to other cognitive abilities and everyday functions.

The findings from this review yield important implications for research on healthy older adults. Analysis revealed that experimental groups (groups that were provided with the SOP training) had larger improvements across most cognitive domains and everyday function variables examined than control groups at all levels of transfer except for one research by (Jones et al., 2013). Retention ranged from 44.0 - 98.7\% of the sample across all studies used in this review, resulting in a rather moderately high adherence rate. In terms of duration, a time span of either 60 minutes or 60 to 75 minutes per session provided the best results in terms of significant improvements in scores across processing speed with effect sizes ranging 
from moderate to high. The higher the amount of total training hours, the better the improvement on both speed of processing and attention measures with larger effect sizes as well. Nevertheless, this could be segregated into total hours of training spread across many continuous sessions or fewer initial training paired with booster trainings to improve performance and effect sizes in these variables. A total number of 4 exercises and above should be used in the SOP training to this cognitive ability. Although lab based training was more frequently used by researchers in these studies, home-based training also resulted in equal performances across the processing speed, with most studies across both implementation venues displaying improvements ranging between a moderate to large effect sizes. Upon completing the training, an overall view showed that moderate to large effect sizes were noted in outcome measures of processing speed in most studies. However, the same is not true for the attentional domains as very few transfers occurred from the SOP training occurred to this domain itself, and among studies that reported some transfer effects, only small to moderate effects were reported. Far transfers to a few cognitive dimensions of memory and everyday functioning of driving, everyday speed and everyday problems were noted, but only at a small to moderate impact level.

Without a doubt, all studies reviewed revealed that SOP training affects the direct measure of speed of processing more than any other variable. Information provided in the earlier sections clearly confirm that majority of studies witnessed a moderate to large size effect of SOP training on participant's performance in the processing speed dimension (Ball et al., 2002; Belchior et al., 2019; Eramudugolla et al., 2017; Mahncke et al., 2006; Rebok et al., 2014; Smith et al., 2009; Willis et al., 2006; Zelinski et al., 2011). Similar findings were reported in Lampit et al (2014) upon analysing 33 studies that reported speed of processing outcomes after participants underwent a range of CCTs, where moderate and statistically significant effect sizes in the dimension was noted. Another systematic review by Sprague et al (2019) mentioned that in CCTs, the most prominent and likely transfer of effects of the training are to be witnessed in the cognitive domains of speed, verbal working memory and visual working memory. Furthermore, Edwards et al (2018) discovered that SOP training displayed mediumsized improvements on speed of processing when it was measured as a proximal outcome across the studies in this review. In studies involving community based samples, large improvements in speed of processing measures were noted. Close magnitudes were visible when comparing effect sizes of adaptive and partially adaptive SOP training on outcome measures in that the former produced larger and the latter produced moderate effect sizes, respectively. Additionally, the SOP training related studies reviewed in this research showed that performance on speed of processing tasks, that were not practiced directly as part of the training process, showed significant small improvements. A strong possibility that larger effect sizes are obtained in this cognitive dimension could be due to the higher the number of participants in a study. Lampit et al (2014) conducted a fixed-analysis that displayed a noticeably larger effect size on studies with large number of participants. Similarly, studies analysed for the purpose of this review with a bigger sample size, such as the ACTIVE trial studies (Ball et al., 2002; Rebok et al., 2014; Tennstedt \& Unverzagt, 2013; Willis et al., 2006) which included 2802 participants and the IMPACT trial studies (Smith et al., 2009; Zelinsky et al., 2011) which included 487 participants reported significantly large effect sizes in speed of processing. 
Only two studies reported witnessed a small to moderate effect size of SOP training on participant's performance across attention related domains (Belchior et al., 2019; Smith et al., 2009). These results were further confirmed as Lampit et al (2014), having reviewed 11 studies that reported outcomes relating to the attentional domain of cognitive abilities mentioned that the effect sizes across these studies were small and non-significant. Conversely, Sprague et al (2019) reported in their systematic review that although cognitive domains of visual attention and executive function were frequently assessed in CCT related research, consistent transfer effects were not discovered in the relevant outcome measures. Similar to the above pattern, far transfer of SOP training to the cognitive ability of memory was witnessed in this research with a small effect size (Belchior et al., 2013; Faust et al., 2020; Zelinski et al., 2011; Zelinski et al., 2014). However, the systematic review and meta-analysis by Edwards et al (2018) reported no significant effect but medium variations on the memory construct post SOP training. A rational reasoning for the above mentioned results could be dedicated to the idea that the generalization of effects obtained through CCTs with specific focal points, such as SOP trainings, are rather limited and may not extend beyond the targeted cognitive ability (Simons et al., 2006). This provides an understanding why conflicting findings have surfaced with regard to measures of attention and other cognitive abilities such as memory. Nevertheless, studies such as Edwards et al (2013b); O'Brien et al (2013) suggest that SOP related training may include elements that primarily improve attention, just as findings of this research has reported. Further affirming this information, Edwards et al (2018) suggested that the SOP training related studies reviewed in their research showed that performance on the cognitive construct of attention, both directly and indirectly practiced as part of the training process, had significant small improvement effects.

Some significant small transfer effects to everyday functions of driving, everyday speed and everyday problems were also reported in the current study (Ball et al., 2010; Belchior et al., 2019; Tennstedt \& Unverzagt, 2013; Willis et al., 2006). Once again, Edwards et al (2018) mentioned that their review on SOP training displayed transfers to real-world abilities, as improvements on SOP performance results in transfers to improved everyday functional performance. In terms of adverse driving events, participants in a SOP training group were $49 \%$ less likely to experience it. In addition to the above, two studies showed that SOP training displayed a small significant effect size on driving mobility. In relation to everyday speed and problems, Edwards et al (2018) also discovered that results from five randomized clinical trials showed small but significant improvement effects on IADL performance.

A well-documented fact is the idea that reduction in speed of processing would eventually lead to a reduction in the abilities of older adults to perform everyday functions. Consequences of this scenario could lead to a longer duration for older adults to perform everyday activities, ultimately reducing their quality of life. Additionally, it also poses a threat to safety and survival measures. With lowered processing speed, older adults may take an increased amount of time to respond to sensory information subjected to threats in their environment (Ball \& Vance, 2007; Vance et al., 2010). Therefore, far transfer effects of SOP training to everyday functioning variables visible in this study has its benefits in preventing the above mentioned circumstances as a result of improved processing speed. As mentioned in Edwards et al (2018), the fact that older adults rated their IADL difficulties as lower is crucial evidence of their abilities to maintain independence. It is reasonable to accept that any 
intervention that produced an improvement on the IADL is certainly beneficial, indicating in the case of this study that SOP training resulting in such far transfers are particularly essential.

Strengths and Limitations of Studies Included in this Review. The strength of studies used in this systematic review relies on the risk of bias of each individual study. Cochrane's Risk of Bias Tool was used to assess the risk of bias of each study in this review. The final review comprised 23 studies, majority of which were reported as good quality studies, revealing low risk of bias. Table 1 lists detailed analysis of the risk of bias across these studies. On the other hand, as all studies selected for this systematic review targeted healthy older adults, a limitation could exist in the longitudinal trials and studies. The health and well-being of participants across all research were measured at relevant points of the research. However, in reporting their findings, some researchers failed to include updates with regard to this information in their studies. Therefore, all research reviewed in this study function under the assumption that the participants functioning, defined as healthy at baseline measurements, were somewhat maintained across the years of research as their data was not eliminated for the final analysis of results in each individual study. In reality, there could be a possibility of some healthy adults showing cognitive declines, mild cognitive impairments or other possible threats that could influence their performance across outcome measures recorded at followup sessions.

Limitations and Recommendations at an Outcome Level. Despite the displayed evidence, there are three limitations that exist in this systematic review. The first limitation targets inconsistencies across outcome measures. Although the focus of this review was centered around the impact of SOP training specifically on transfer effects to processing speed, attentional domain, other cognitive abilities and everyday functioning, each study utilized various instruments to measure performances across each variable. As an example, some example of processing speed outcome measures are exercises adapted from the Brain $\mathrm{HQ}$ training program (Belchior et al. 2019; Mahncke et al., 2006; Smith et al., 2009; Zelinski et al., 2014), Useful Field of View measure (Ball et al., 2002; Belchior et al., 2013; Belchior et al., 2019; Edwards et al., 2002; Edwards et al., 2013a; Eramudugolla et al., 2017; Smith et al., 2018) and Wechsler Adult Intelligence Scale-IV Cancellation (Faust et al., 2020). Therefore, results obtained from each of these measures may not be equivalent in magnitude. In future reviews, it is recommended that all selected articles include a similar outcome measure (with minimal variability) in assessing performance on each variable.

Secondly, large variability across training techniques and implementations made it challenging to determine the best dosage for highly effective studies. In Eramudugolla et al. (2017), information on exact time duration per training session was not available. A number of studies included a range of time durations rather than specific and exact duration per training session as well, such as 60 to 75 minutes (for most ACTIVE trial studies) and 50 to 60 minutes (Smith et al., 2018). Some studies even mentioned that duration details provided are inclusive of break time for participants, but unclear description of this information across studies resulted in a lack of clarity on the total amount of time spent solely at training per session. For further information, please refer to table 2 . The large variability in this dimension made it difficult to determine the optimal dosage for CCTs that are the most effective. It is recommended that each individual research article should include clear specification and 
details of interventions implemented, possibly following a standardized and specific guideline, to ensure no visible gaps or doubts in this element.

Lastly, there is a possibility that a few studies that were eligible to be selected for this review were not analyzed due to the inability to obtain full-text documents either through database search or from the independent researchers and incomplete articles (such as missing a particular section of the article). It is recommended in future studies, that these researches are included as part of the review process, given the possibility of discovering all articles that meet the inclusion and exclusion criteria of this review.

\section{Implication of Study}

The implication of this review is recognizing the Brain HQ's SOP training as a clinically meaningful CCT. The results of the current study clearly demonstrate that this particular SOP training has the capacity to not only generate great effects via near transfers to measures of processing speed, but also the ability to generalize training effects via far transfers to everyday functioning, as observed through significant small effect sizes on participants' performances on IADL and TIADL. The ability of the SOP training to not only improve a skill or underlying ability but also a performance on everyday functions shows the capability of this training to create clinically meaningful effects that enhances the lives of older adults and their daily functioning. CCTs such as the Brain HQ by Posit Science are examples of interventions that are low in risk and cost without creating much burden on participants, mainly due to its advantages, ease of use and accessibility, that a program as such can be utilized for practice on almost any readily available screen (including mobile phones, tablets, laptops and desktops). Although only a significantly small effect size of transfer of SOP training to IADL and TIADL was noted, this does not indicate that the effects obtained are not clinically meaningful, as orthodoxly mentioned by Cohen. Most cognitive training studies in particular usually generate small effect sizes (Edwards et al., 2018). In Hindin and Zelinski (2012), a metaanalysis showed that both physical exercise and process-based cognitive training have similar abilities to improve overall cognition, yet individuals still have a higher regard for and genuinely accept physical exercise as a means to do so more than the other technique. Therefore, it is timely to recognize, acknowledge and recommend the benefits of Brain HQ's SOP training program in particular, to enhance older adults' quality of life.

\section{Conclusion}

The field of CCTs is upcoming yet poses a great challenge to conventional cognitive training theories. For every article or study released in attempt to question the effectiveness of CCTs, many studies are being conducted to prove its efficiency. As some major findings of this systematic review clearly depict, moderate to large effects in processing speed and small to moderate effects across attentional and other cognitive domains as well as everyday functioning variables are witnessed in trained individuals. Moderately high adherence rates were prevalent in all studies. Regardless of venue (lab-based versus home-based), trainings utilizing four exercises or more, with a duration of 60 minutes and above and higher amounts of total training hours reflected moderate to large effect sizes in the studies reviewed.

The Brain HQ's SOP training program has been utilized widely in research, making it the most researched training program owned by Posit Science. The proclamation of such evidencebased interventions are thoroughly convincing and is recommended for training healthy older 
adults in an attempt to delay cognitive declination and improve their quality of life. However, statistically objective reviews concerning the effectiveness of this particular CCT is yet lacking. It is recommended that future systematic reviews, with a sole focus on the Brain HQ SOP training, include a meta-analysis component to further ascertain the effects of this training on cognitive constructs of speed of processing, attention, other cognitive abilities and everyday functioning variables as it increases the generalizability of each individual study. Precise estimation of effect sizes would provide a clear depiction of benefits conferred from the intervention, increasing clarity of conclusiveness between and within each individual study as well (Lee, 2019).

Highlighted in its efficacy, Brain HQ's SOP training easily overshadows other sister training programs targeted at improving various cognitive abilities. As noted from the findings in this review, effectiveness of the SOP training program on improving cognitive abilities in the attentional dimensions of healthy older adults are not as immense. Therefore, future studies should consider including Brain HQ's attention related training to measure its effect on attentional domains instead, given that a higher possibility of effect transference from a welldesigned specifically targeted intervention may occur, ultimately creating greater opportunity to enhance this cognitive ability in healthy older adults. A comparison between the impact of SOP training versus attention training on attentional domains could be made as well to provide further clarity on the effectiveness of each respective intervention whilst enhancing the overall functionality of the Brain $\mathrm{HQ}$ program itself.

Theoretically, this systematic review has further contributed to the ideas underlying aging and brain plasticity. CCTs have the capacity to enhance brain functioning as individuals age, furthermore if they are in good health. Every research discussed in this study shows concrete empirical evidence in the ability of a specifically well-designed CCT to progressively improve cognitive functioning of healthy older adults, some to a great extent. This discovery has further ascertained the neuroplasticity of the aging brain in its ability to assimilate and adapt to new knowledge being transmitted via CCTs that enables improved functioning and greater quality of life in the elderly.

\section{Acknowledgment}

We gratefully acknowledge the funding support by the Long-Term Research Grant Scheme (LRGS) and Tabung Agihan Penyelidikan, UKM (TAP). No: LRGS/1/2019/SYUC/02/1/3 and TAPK006628.

\section{References}

Acevedo, A., \& Loewenstein, D. A. (2007). Nonpharmacological Cognitive Interventions in Aging and Dementia. Journal of Geriatric Psychiatry and Neurology, 20(4), 239-249. https://doi.org/10.1177/0891988707308808

Anderson, S., White-Schwoch, T., Parbery-Clark, A., \& Kraus, N. (2013). Reversal of AgeRelated Neural Timing Delays with Training. Proceedings of the National Academy of Sciences, 110(11), 4357-4362. https://doi.org/10.1073/pnas.1213555110

Anderson, S., White-Schwoch, T., Choi, H. J., \& Kraus, N. (2014). Partial Maintenance of Auditory-Based Cognitive Training Benefits in Older Adults. Neuropsychologia, 62, 286296. https://doi.org/10.1016/j.neuropsychologia.2014.07.034 
Ball, K., Berch, D. B., Helmers, K. F., Jobe, J. B., Leveck, M. D., Marsiske, M., Morris, J. N., Rebok, G. W., Smith, D. M., Tennstedt, S. L., Unverzagt, F. W., Willis, S. L., \& for the ACTIVE Study Group. (2002). Effects of Cognitive Training Interventions with Older Adults. JAMA, 288(18), 2271. https://doi.org/10.1001/jama.288.18.2271

Ball, K. K., \& Vance. D. E. (2007). Everyday life applications and rehabilitation of processing speed deficits: aging as a model for clinical populations. In J. H. DeLuca, J. \& Kalmar (Ed.), Information processing speed in clinical populations (pp. 243-263). New York: Taylor \& Francis.

Ball, K., Edwards, J. D., Ross, L. A., \& McGwin Jr., G. (2010). Cognitive Training Decreases Motor Vehicle Collision Involvement of Older Drivers. Journal of the American Geriatrics Society, 58(11), 2107-2113. https://doi.org/10.1111/j.15325415.2010.03138.x

Belchior, P., Marsiske, M., Sisco, S. M., Yam, A., Bavelier, D., Ball, K., \& Mann, W. C. (2013). Video Game Training to Improve Selective Visual Attention in Older Adults. Computers in Human Behavior, 29(4), 1318-1324. https://doi.org/10.1016/j.chb.2013.01.034

Belchior, P., Yam, A., Thomas, K. R., Bavelier, D., Ball, K. K., Mann, W. C., \& Marsiske, M. (2019). Computer and Videogame Interventions for Older Adults' Cognitive and Everyday Functioning. Games for Health Journal, 8(2), 129-143. https://doi.org/10.1089/g4h.2017.0092

Blackwood, J., Shubert, T., Fogarty, K., \& Chase, C. (2016). The Impact of a Home-Based Computerized Cognitive Training Intervention on Fall Risk Measure Performance in Community Dwelling Older Adults, A Pilot Study. The Journal of Nutrition, Health \& Aging, 20(2), 138-145. https://doi.org/10.1007/s12603-015-0598-5

Castells-Sánchez, A., Roig-Coll, F., Lamonja-Vicente, N., Altés-Magret, M., Torán-Monserrat, P., Via, M., García-Molina, A., Tormos, J. M., Heras, A., Alzamora, M. T., Forés, R., Pera, G., Dacosta-Aguayo, R., Soriano-Raya, J. J., Cáceres, C., Montero-Alía, P., Montero-Alía, J. J., Jimenez-Gonzalez, M. M., Hernández-Pérez, M., ... Mataró, M. (2019). Effects and Mechanisms of Cognitive, Aerobic Exercise, and Combined Training on Cognition, Health, and Brain Outcomes in Physically Inactive Older Adults: The Projecte Moviment Protocol. Frontiers in Aging Neuroscience, 11. https://doi.org/10.3389/fnagi.2019.00216

Chudler, E. H. (n.d.). Brain Plasticity: What Is It? Learning and Memory. Retrieved June 15, 2020, from https://faculty.washington.edu/chudler/plast.html

Darwish, S., Ahmed, U., \& Pahi, M. H. (2020). Innovative Work Behavior During COVID-19 for Medical Representative in the Pharmaceutical Industry: Test of a Moderation Model in Bahrain. International Journal of Pharmaceutical Research. 12(4), 19271934. doi.org/10.31838/ijpr/2020.12.04.277

Edwards, J. D., Wadley, V. G., Myers, R. S., Roenker, D. L., Cissell, G. M., \& Ball, K. K. (2002). Transfer of a Speed of Processing Intervention to Near and Far Cognitive Functions. Gerontology, 48(5), 329-340. https://doi.org/10.1159/000065259

Edwards, J. D., Valdes, E. G., Peronto, C., Castora-Binkley, M., Alwerdt, J., Andel, R., \& Lister, J. J. (2013a). The Efficacy of InSight Cognitive Training to Improve Useful Field of View Performance: A Brief Report. The Journals of Gerontology Series B: Psychological Sciences and Social Sciences, 70(3), 417-422. https://doi.org/10.1093/geronb/gbt113

Edwards, J. D., Ruva, C. L., O’Brien, J. L., Haley, C. B., \& Lister, J. J. (2013b). An Examination of Mediators of the Transfer of Cognitive Speed of Processing Training to Everyday 
Functional Performance. Psychology and Aging, 28(2), 314-321.

https://doi.org/10.1037/a0030474

Edwards, J. D., Fausto, B. A., Tetlow, A. M., Corona, R. T., \& Valdés, E. G. (2018). Systematic Review and Meta-Analyses of Useful Field of View Cognitive Training. Neuroscience \& Biobehavioral Reviews, 84, 72-91. https://doi.org/10.1016/j.neubiorev.2017.11.004 Eramudugolla, R., Kiely, K. M., Chopra, S., \& Anstey, K. J. (2017). Effect of Speed of Processing Training on Older Driver Screening Measures. Frontiers in Aging Neuroscience, 9. https://doi.org/10.3389/fnagi.2017.00338

Faust, M. E., Multhaup, K. S., Ong, M. S., Demakis, G. J., \& Balz, K. G. (2020). Exploring the Specificity, Synergy, and Durability of Auditory and Visual Computer Gameplay Transfer Effects in Healthy Older Adults. The Journals of Gerontology: Series B, 75(6), 11701180. https://doi.org/10.1093/geronb/gbz096

Fitzgerald, S. (2017). Is successful brain training fake news? Neurologists parse out the messaging for patients. Neurology Today.

https://journals.Iww.com/neurotodayonline/Fulltext/2017/04060/Is_Successful_Brain_ Training_Fake_News_.6.aspx

Griffith-Greene, M. M. (2015). Brain training games: No proof they prevent cognitive decline. $C B C$ News Canada Online. https://www.cbc.ca/news/health/brain-traininggames-no-proof-they-prevent-cognitive-decline-1.3025212

Hindin, S. B., \& Zelinski, E. M. (2012). Extended Practice and Aerobic Exercise Interventions Benefit Untrained Cognitive Outcomes in Older Adults: A Meta-Analysis. Journal of the American Geriatrics Society, 60(1), 136-141. https://doi.org/10.1111/j.15325415.2011.03761.x

Hirschmann, R. (2019). Share of aging population Malaysia 2014-2019. Statista.Com. https://www.statista.com/statistics/713529/malaysia-aging-population/\#: :text=In 2019\%2C it was estimated,years stood at 6.7 percent.

Jobe, J. B., Smith, D. M., Ball, K., Tennstedt, S. L., Marsiske, M., Willis, S. L., Rebok, G. W., Morris, J. N., Helmers, K. F., Leveck, M. D., \& Kleinman, K. (2001). ACTIVE: A Cognitive Intervention Trial to Promote Independence in Older Adults. Controlled Clinical Trials, 22(4), 453-479. https://doi.org/10.1016/S0197-2456(01)00139-8

Jones, R. N., Marsiske, M., Ball, K., Rebok, G., Willis, S. L., Morris, J. N., \& Tennstedt, S. L. (2013). The ACTIVE Cognitive Training Interventions and Trajectories of Performance Among Older Adults. Journal of Aging and Health, 25(8_suppl), 186S-208S. https://doi.org/10.1177/0898264312461938

Kua, Z. J., Valenzuela, M., \& Dong, Y. (2019). Can Computerized Cognitive Training Improve Cognition in Patients with Heart Failure? The Journal of Cardiovascular Nursing, 34(2), E19-E27. https://doi.org/10.1097/JCN.0000000000000558

Lampit, A., Hallock, H., \& Valenzuela, M. (2014). Computerized Cognitive Training in Cognitively Healthy Older Adults: A Systematic Review and Meta-Analysis of Effect Modifiers. PLoS Medicine, 11(11), e1001756. https://doi.org/10.1371/journal.pmed.1001756

Lee, Y. H. (2019). Strengths and Limitations of Meta-Analysis. The Korean Journal of Medicine, 94(5), 391-395. https://doi.org/10.3904/kjm.2019.94.5.391

Mafauzy, M. (2000). The problems and challenges of the aging population of Malaysia. The Malaysian Journal of Medical Sciences, 7(1), 1-3. PMID: 22844207

Mahncke, H. W., Connor, B. B., Appelman, J., Ahsanuddin, O. N., Hardy, J. L., Wood, R. A., Joyce, N. M., Boniske, T., Atkins, S. M., \& Merzenich, M. M. (2006). Memory 
Enhancement in Healthy Older Adults Using a Brain Plasticity-Based Training Program: A randomized, Controlled Study. Proceedings of the National Academy of Sciences, 103(33), 12523-12528. https://doi.org/10.1073/pnas.0605194103

Marusic, U., Verghese, J., \& Mahoney, J. R. (2018). Cognitive-Based Interventions to Improve Mobility: A Systematic Review and Meta-analysis. Journal of the American Medical Directors Association, 19(6), 484-491.e3. https://doi.org/10.1016/j.jamda.2018.02.002

Methley, A. M., Campbell, S., Chew-Graham, C., McNally, R., \& Cheraghi-Sohi, S. (2014). PICO, PICOS and SPIDER: A Comparison Study of Specificity and Sensitivity in Three Search Tools for Qualitative Systematic Reviews. BMC Health Services Research, 14(1), 579. https://doi.org/10.1186/s12913-014-0579-0

Mishra, J., Rolle, C., \& Gazzaley, A. (2015). Neural Plasticity Underlying Visual Perceptual Learning in Aging. Brain Research, 1612, 140-151. https://doi.org/10.1016/j.brainres.2014.09.009

Nguyen, L., Murphy, K., \& Andrews, G. (2019). Immediate and Long-Term Efficacy of Executive Functions Cognitive Training in Older Adults: A Systematic Review and MetaAnalysis. Psychological Bulletin, 145(7), 698-733. https://doi.org/10.1037/bul0000196

O’Brien, J. L., Edwards, J. D., Maxfield, N. D., Peronto, C. L., Williams, V. A., \& Lister, J. J. (2013). Cognitive Training and Selective Attention in the Aging Brain: An Electrophysiological Study. Clinical Neurophysiology, 124(11), 2198-2208. https://doi.org/10.1016/j.clinph.2013.05.012

Pauwels, L., Chalavi, S., \& Swinnen, S. P. (2018). Aging and Brain Plasticity. Aging, 10(8), 1789-1790. https://doi.org/10.18632/aging.101514

Posit Science. (2020). Brain HQ. https://www.brainhq.com/

PRISMA GROUP. (2020, May 28). PRISMA transparent reporting of systematic reviews and meta-analyses. http://www.prisma-statement.org/

Rebok, G. W., Ball, K., Guey, L. T., Jones, R. N., Kim, H.-Y., King, J. W., Marsiske, M., Morris, J. N., Tennstedt, S. L., Unverzagt, F. W., \& Willis, S. L. (2014). Ten-Year Effects of the Advanced Cognitive Training for Independent and Vital Elderly Cognitive Training Trial on Cognition and Everyday Functioning in Older Adults. Journal of the American Geriatrics Society, 62(1), 16-24. https://doi.org/10.1111/jgs.12607

Shah, T. M., Weinborn, M., Verdile, G., Sohrabi, H. R., \& Martins, R. N. (2017). Enhancing Cognitive Functioning in Healthy Older Adults: a Systematic Review of the Clinical Significance of Commercially Available Computerized Cognitive Training in Preventing Cognitive Decline. Neuropsychology Review, 27(1), 62-80. https://doi.org/10.1007/s11065-016-9338-9

Sharpe, C., Holup, A. A., Hansen, K. E., \& Edwards, J. D. (2014a). Does Self-Efficacy Affect Responsiveness to Cognitive Speed of Processing Training? Journal of Aging and Health, 26(5), 786-806. https://doi.org/10.1177/0898264314531615

Sharpe, C., Holup, A. A.; Hansen, K. E.; Edwards, J. D. (2014b). Predicting Response to Cognitive Speed of Processing Training with Measures of Self-Efficacy. Journal of Aging and Health, 26(5), 786-806.

https://www.ncbi.nlm.nih.gov/pmc/articles/PMC4529382/?report=classic

Simons, D. J., Boot, W. R., Charness, N., Gathercole, S. E., Chabris, C. F., Hambrick, D. Z., \& Stine-Morrow, E. A. L. (2016). Do "Brain-Training" Programs Work? Psychological Science in the Public Interest, 17(3), 103-186. https://doi.org/10.1177/1529100616661983 
Simpson, T., Camfield, D., Pipingas, A., Macpherson, H., \& Stough, C. (2012). Improved Processing Speed: Online Computer-based Cognitive Training in Older Adults. Educational Gerontology, 38(7), 445-458. https://doi.org/10.1080/03601277.2011.559858

Smith, G. E., Housen, P., Yaffe, K., Ruff, R., Kennison, R. F., Mahncke, H. W., \& Zelinski, E. M. (2009). A Cognitive Training Program Based on Principles of Brain Plasticity: Results from the Improvement in Memory with Plasticity-based Adaptive Cognitive Training (IMPACT) Study. Journal of the American Geriatrics Society, 57(4), 594-603. https://doi.org/10.1111/j.1532-5415.2008.02167.x

Smith, M., Jones, M. P., Dotson, M. M., \& Wolinsky, F. D. (2018). Speed-of-Processing Training in Assisted and Independent Living: A Randomized Controlled Trial. Journal of the American Geriatrics Society, 66(8), 1538-1545. https://doi.org/10.1111/jgs.15423

Sood, P., Kletzel, S. L., Krishnan, S., Devos, H., Negm, A., Hoffecker, L., Machtinger, J., Hu, X., \& Heyn, P. C. (2019). Nonimmersive Brain Gaming for Older Adults with Cognitive Impairment: A Scoping Review. The Gerontologist, 59(6), e764-e781. https://doi.org/10.1093/geront/gny164

Sprague, B. N., Freed, S. A., Webb, C. E., Phillips, C. B., Hyun, J., \& Ross, L. A. (2019). The Impact of Behavioral Interventions on Cognitive Function in Healthy Older Adults: A Systematic Review. Ageing Research Reviews, 52, 32-52. https://doi.org/10.1016/j.arr.2019.04.002

Szelag, E., \& Skolimowska, J. (2012). Cognitive Function in Elderly can be Ameliorated by Training in Temporal Information Processing. Restorative Neurology and Neuroscience, 30(5), 419-434. https://doi.org/10.3233/RNN-2012-120240

ten Brinke, L. F., Davis, J. C., Barha, C. K., \& Liu-Ambrose, T. (2017). Effects of Computerized Cognitive Training on Neuroimaging Outcomes in Older Adults: A Systematic Review. BMC Geriatrics, 17(1), 139. https://doi.org/10.1186/s12877-017-0529-x

Tennstedt, S. L., \& Unverzagt, F. W. (2013). The ACTIVE Study: Study Overview and Major Findings. Journal of Aging and Health, 25(8_suppl), 3S-20S.

https://doi.org/10.1177/0898264313518133

United Nations. (2020, June 15). Ageing. https://www.un.org/en/sections/issuesdepth/ageing/

Vance, D. E., Heaton, K., Fazeli, P. L., \& Ackerman, M. L. (2010). Aging, Speed of Processing Training, and Everyday Functioning: Implications for Practice and Research. Activities, Adaptation \& Aging, 34(4), 276-291. https://doi.org/10.1080/01924788.2010.523867

Willis, S. L., Tennstedt, S. L., Marsiske, M., Ball, K., Elias, J., Koepke, K. M., Morris, J. N., Rebok, G. W., Unverzagt, F. W., Stoddard, A. M., Wright, E., \& ACTIVE Study Group, for the. (2006). Long-term Effects of Cognitive Training on Everyday Functional Outcomes in Older Adults. JAMA, 296(23), 2805. https://doi.org/10.1001/jama.296.23.2805

Wolinsky, F. D., Vander Weg, M. W., Howren, M. B., Jones, M. P., Martin, R., Luger, T. M., Duff, K., \& Dotson, M. M. (2011). Interim Analyses from a Randomised Controlled Trial to Improve Visual Processing Speed in Older Adults: The lowa Healthy and Active Minds Study. BMJ Open, 1(2), e000225-e000225. https://doi.org/10.1136/bmjopen-2011000225

Wolinsky, F. D., Vander Weg, M. W., Howren, M. B., Jones, M. P., \& Dotson, M. M. (2013). A Randomized Controlled Trial of Cognitive Training Using a Visual Speed of Processing Intervention in Middle Aged and Older Adults. PLOS ONE, 8(5), e61624. https://doi.org/10.1371/journal.pone.0061624 
Zelinski, E. M., Spina, L. M., Yaffe, K., Ruff, R., Kennison, R. F., Mahncke, H. W., \& Smith, G. E. (2011). Improvement in Memory with Plasticity-Based Adaptive Cognitive Training: Results of the 3-Month Follow-Up. Journal of the American Geriatrics Society, 59(2), 258-265. https://doi.org/10.1111/j.1532-5415.2010.03277.x

Zelinski, E. M., Peters, K. D., Hindin, S., Petway, K. T., \& Kennison, R. F. (2014). Evaluating the Relationship Between Change in Performance on Training Tasks and on Untrained Outcomes. Frontiers in Human Neuroscience, 8. https://doi.org/10.3389/fnhum.2014.00617 


\section{Appendices}

\section{APPENDIX 1}

PRISMA 2009 Flow Diagram
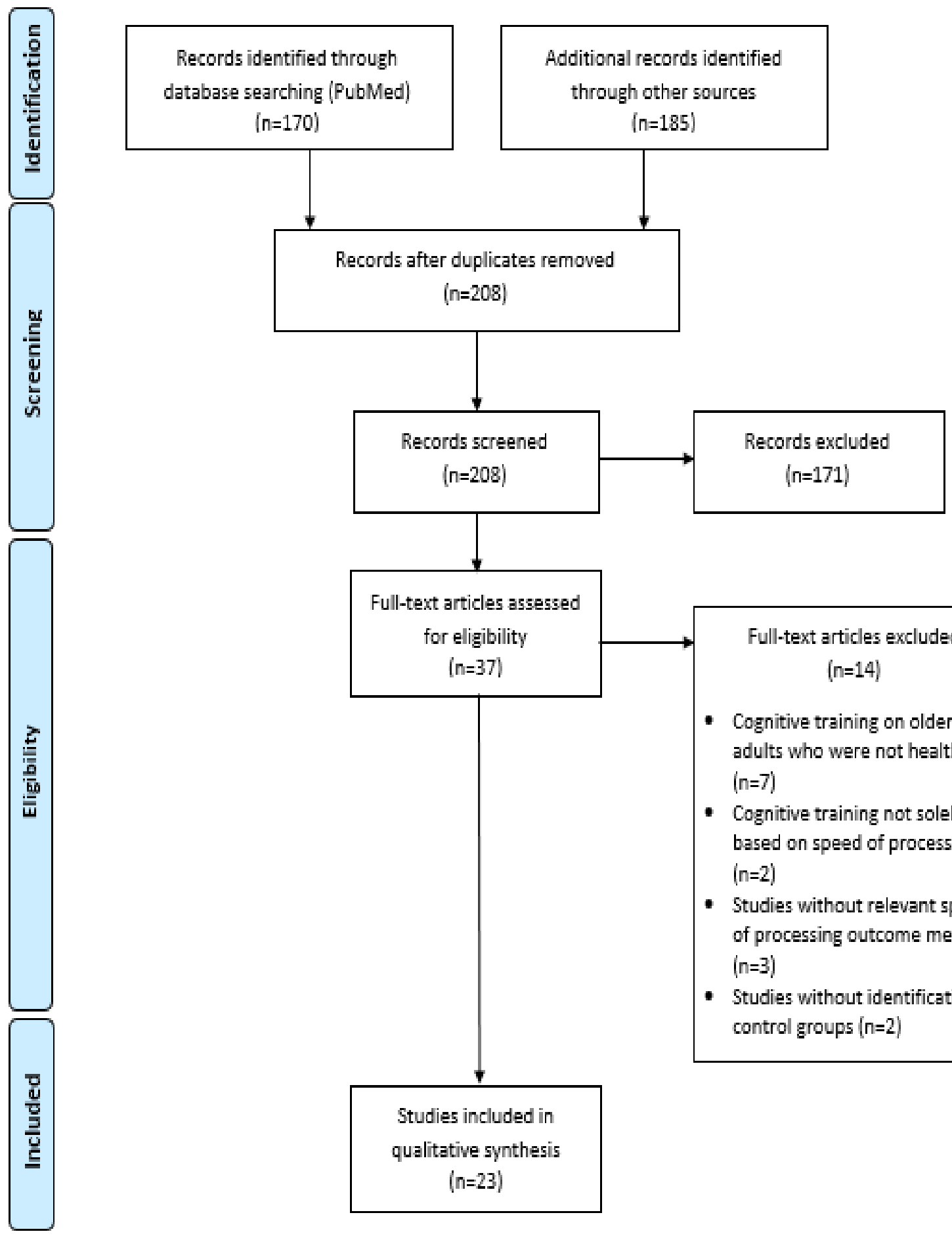

Full-text articles assessed for eligibility (n=37)

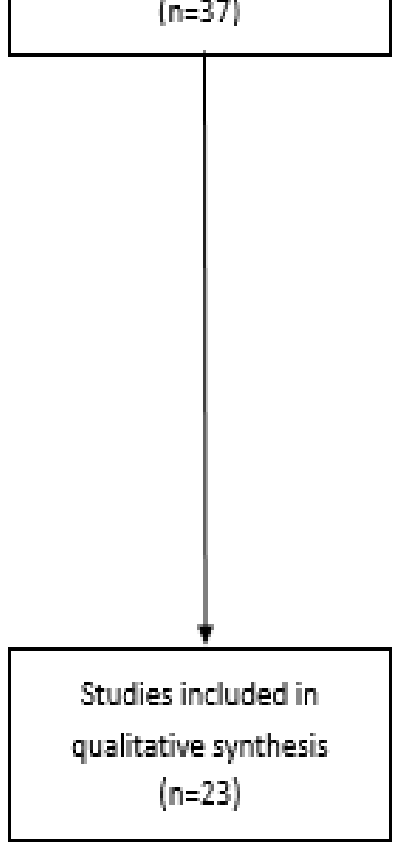

Full-text articles excluded

$$
\text { (n=14) }
$$

- Cognitive training on older adults who were not healthy $(n=7)$

- Cognitive training not solely based on speed of processing $(n=2)$

- Studies without relevant speed of processing outcome measure $(n=3)$

- Studies without identification of control groups ( $n=2)$

Figure 1: PRISMA Flow Diagram Displaying Flow of Studies in the Systematic Review 
INTERNATIONAL JOURNAL OF ACADEMIC RESEARCH IN BUSINESS AND SOCIAL SCIENCES Vol. 10, No. 11, 2020, E-ISSN: 2222-6990 @ 2020 HRMARS

\section{APPENDIX 2}

Table 1: Risk of Bias Assessments at a Study Level in Studies Utilizing Posit Science's SOP CCT on Healthy Older Adults

\begin{tabular}{|c|c|c|c|c|c|c|c|c|}
\hline Study & $\begin{array}{l}\text { Random } \\
\text { Sequence } \\
\text { Generation }\end{array}$ & \begin{tabular}{c|} 
Allocation \\
Concealment
\end{tabular} & $\begin{array}{l}\text { Selective } \\
\text { Reporting }\end{array}$ & $\begin{array}{l}\text { Other } \\
\text { Bias }\end{array}$ & $\begin{array}{c}\text { Blinding of } \\
\text { Participants } \\
\text { and } \\
\text { Personnel }\end{array}$ & $\begin{array}{c}\text { Blinding of } \\
\text { Outcome } \\
\text { Assessment }\end{array}$ & $\begin{array}{c}\text { Incomplete } \\
\text { Data }\end{array}$ & $\begin{array}{c}\text { Study } \\
\text { Quality (by } \\
\text { AHRQ } \\
\text { Standards) }\end{array}$ \\
\hline $\begin{array}{l}\text { Anderson et al. } \\
\text { (2013) }\end{array}$ & $\oplus$ & ?? & $\oplus$ & (?) & ( ) & $\oplus$ & (†) & Fair \\
\hline $\begin{array}{l}\text { Anderson et al. } \\
(2014)\end{array}$ & $(+)$ & (?) & $(+)$ & (?) & $(+$ & ( & $(+)$ & Fair \\
\hline Ball et al. (2002) & (†) & (†) & (†) & (†) & (†) & (†) & $\oplus$ & Good \\
\hline Ball et al. (2010) & $\oplus$ & (†) & (†) & (†) & (†) & $\oplus$ & (†) & Good \\
\hline $\begin{array}{l}\text { Belchion et al. } \\
\text { (2013) }\end{array}$ & (†) & (?) & (†) & (†) & (†) & (†) & (†) & Fair \\
\hline $\begin{array}{l}\text { Belchion et al. } \\
\text { (2019) }\end{array}$ & (?) & ?? & (†) & $\oplus$ & (†) & (†) & (†) & Fair \\
\hline $\begin{array}{l}\text { Edwards et al. } \\
(2002)\end{array}$ & ( & (?) & (†) & (?) & (†) & & $(+)$ & Poor \\
\hline $\begin{array}{l}\text { Edwards et al. } \\
\text { (2013a) }\end{array}$ & (†) & (?) & (†) & (†) & (†) & (?) & $\oplus$ & Fair \\
\hline $\begin{array}{l}\text { Examudugalla et } \\
\text { al. (2017) }\end{array}$ & $\Theta$ & (-) & (†) & 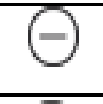 & $(\oplus$ & (?) & $(+$ & Poor \\
\hline $\begin{array}{l}\text { Faust et al. } \\
(2020)\end{array}$ & (†) & (†) & (†) & (†) & (†) & (†) & (†) & Good \\
\hline $\begin{array}{l}\text { Jones et al. } \\
\text { (2013) }\end{array}$ & (†) & (†) & (†) & (†) & (†) & (†) & ( & Good \\
\hline $\begin{array}{l}\text { Mahncke et al. } \\
(2006)\end{array}$ & $(+)$ & (†) & (†) & (†) & (†) & (†) & $(+)$ & Good \\
\hline $\begin{array}{l}\text { Mishra et al. } \\
\text { (2015) }\end{array}$ & (†) & (†) & (†) & (†) & (†) & (†) & (†) & Good \\
\hline $\begin{array}{l}\text { O'Brien et al. } \\
(2013)\end{array}$ & (?) & (?) & $(+)$ & (?) & (†) & (?) & $(+)$ & Poor \\
\hline $\begin{array}{l}\text { Beberket al. } \\
(2014)\end{array}$ & (†) & (†) & (†) & (†) & (†) & (†) & (†) & Good \\
\hline $\begin{array}{l}\text { Sharpe et al. } \\
\text { (2014a) }\end{array}$ & (†) & (†) & (†) & $(+)$ & (†) & (†) & (†) & Good \\
\hline $\begin{array}{l}\text { Sharpe et al. } \\
\text { (2014b) }\end{array}$ & (†) & $\oplus$ & (†) & (†) & (†) & (†) & (†) & Good \\
\hline $\begin{array}{l}\text { Smith et al. } \\
(2009)\end{array}$ & (†) & (†) & (†) & (†) & ( & $\oplus$ & (†) & Good \\
\hline $\begin{array}{l}\text { Smith et al. } \\
(2018)\end{array}$ & $(+)$ & $(+)$ & (†) & ( & (†) & (†) & $(\oplus$ & Good \\
\hline
\end{tabular}


INTERNATIONAL JOURNAL OF ACADEMIC RESEARCH IN BUSINESS AND SOCIAL SCIENCES Vol. 10, No. 11, 2020, E-ISSN: 2222-6990 @ 2020 HRMARS

\begin{tabular}{|l|c|c|c|c|c|c|c|c|}
\hline $\begin{array}{l}\text { Jeonstedt \& } \\
\text { Yoverzagt } \\
\text { (2013) }\end{array}$ & $\oplus$ & $\oplus$ & $\oplus$ & $\oplus$ & $\oplus$ & $\oplus$ & $\oplus$ & Good \\
\hline $\begin{array}{l}\text { Willis et al. } \\
\text { (2006) }\end{array}$ & $\oplus$ & $\oplus$ & $\oplus$ & $\oplus$ & $\oplus$ & $\oplus$ & $\oplus$ & Good \\
\hline $\begin{array}{l}\text { Zelinski et al. } \\
\text { (2011) }\end{array}$ & $\oplus$ & $\oplus$ & $\oplus$ & $\oplus$ & $\oplus$ & $\oplus$ & $\oplus$ & Good \\
\hline $\begin{array}{l}\text { Zelinski et al. } \\
\text { (2014) }\end{array}$ & $\oplus$ & $\oplus$ & $\oplus$ & $\oplus$ & $\oplus$ & $\oplus$ & $\oplus$ & Good \\
\hline
\end{tabular}

Key: $\quad \oplus$ = Low risk of bias; $\quad(?)=$ Unclear risk of bias; $\quad \odot$ = High risk of bias Abbreviations: $C C T=$ Computerized Cognitive Training 
INTERNATIONAL JOURNAL OF ACADEMIC RESEARCH IN BUSINESS AND SOCIAL SCIENCES

Vol. 10, No. 11, 2020, E-ISSN: $2222-6990$ @ 2020 HRMARS

\section{Appendix 3}

Table 2: Summary of Study Characteristics, Intervention and Control Condition Features and Cognitive Training Outcomes for Studies Included in the Qualitative Review.

\begin{tabular}{|c|c|c|c|c|c|c|c|c|c|c|c|}
\hline \multicolumn{3}{|c|}{ Study Characteristics } & \multicolumn{5}{|c|}{ Intervention } & \multirow{2}{*}{$\begin{array}{c}\begin{array}{c}\text { Control } \\
\text { Condition }\end{array} \\
\text { Type/ } \\
\text { Activity }\end{array}$} & \multicolumn{3}{|c|}{ Cognitive Training Outcomes } \\
\hline Study & $\begin{array}{c}\text { Sample } \\
\text { (n) }\end{array}$ & $\begin{array}{l}\text { Mean } \\
\text { Age } \\
(\mathrm{SD}) \\
\end{array}$ & $\begin{array}{c}\text { Session } \\
\text { Duration } \\
\text { (mins) }\end{array}$ & $\begin{array}{c}\text { Sessions/ } \\
\text { Weeks }\end{array}$ & $\begin{array}{c}\text { Total } \\
\text { Training } \\
\text { (hrs) }\end{array}$ & $\begin{array}{c}\text { No. of } \\
\text { Exercises } \\
\text { Utilized } \\
\end{array}$ & Venue & & Processing Speed & Attention & $\begin{array}{c}\text { Transfer to Other } \\
\text { Cognitive abilities or } \\
\text { Everyday Functions }\end{array}$ \\
\hline $\begin{array}{l}\text { Ball et al. } \\
\text { (2002) }\end{array}$ & $\begin{array}{l}\text { TGM: } \\
\text { 703 } \\
\text { TGR: } 699 \\
\text { TGS: } \\
\text { 702* } \\
\text { CG: } 698 \\
\text { Total (n): } \\
2802 \\
\mid \\
\text { Booster } \\
\text { Training } \\
\text { TGM: } \\
\text { 283 } \\
\text { TGR: } 301 \\
\text { TGS: } \\
\text { 295* }\end{array}$ & $\begin{array}{l}73.60 \\
(6.90)\end{array}$ & $\begin{array}{l}\text { Initial: } \\
60-75 \\
\\
\text { Booster: } \\
75\end{array}$ & $\begin{array}{l}\text { Initial: } \\
\text { 10s/5-6w } \\
\\
\text { Booster: } \\
\text { 4s/2-3w }\end{array}$ & $\begin{array}{l}\text { Initial: } 10 \text { - } \\
12.5 \\
\text { Booster: } 5\end{array}$ & 4 & Lab & $\begin{array}{l}\text { Passive/ } \\
\text { No contact } \\
\text { CG }\end{array}$ & $\begin{array}{l}\text {-Training effects were } \\
\text { significant in TG on } \\
\text { proximal outcomes at Post- } \\
\text { test, } 1^{\text {st }} \text { and } 2^{\text {nd }} \text { year } \\
\text { assessments reporting } \\
\text { effect sizes of }-1.463,- \\
1.212 \text { and }-0.867 \\
\text { respectively. } \\
\text {-Training effects were } \\
\text { significant in TG who } \\
\text { received booster training } \\
\text { on proximal outcomes at } \\
1^{\text {st }} \text { and } 2^{\text {nd }} \text { year } \\
\text { assessments reporting } \\
\text { effect sizes of -0.919 and - } \\
0.347 \text { respectively. } \\
\text {-Booster effects were noted } \\
\text { in TG showing reliable } \\
\text { gains in the trained domain } \\
\text { (Booster - } 92 \%, N o \\
\text { booster - } 68 \% \text { and CG - } \\
32 \%) \text {. }\end{array}$ & - & $\begin{array}{l}\text {-No significant transfer effects } \\
\text { of initial and booster training } \\
\text { in TG to everyday problem } \\
\text { solving, ADL and IADL } \\
\text { functioning, everyday speed } \\
\text { and driving habits were } \\
\text { observed across all assessment } \\
\text { points. }\end{array}$ \\
\hline $\begin{array}{l}\text { Willis et al. } \\
\text { (2006) }\end{array}$ & $\begin{array}{l}\text { TGM: } \\
\text { 703 } \\
\text { TGR: } 699 \\
\text { TGS: } \\
\text { 702* } \\
\text { CG: } 698 \\
\text { Total (n): } \\
2802 \\
\\
\text { Booster } \\
\text { Training } \\
\text { TGM: } \\
\text { 283 } \\
\text { TGR: } 301 \\
\text { TGS: } \\
\text { 295* }\end{array}$ & $\begin{array}{l}73.60 \\
(6.90)\end{array}$ & $\begin{array}{l}\text { Initial: } \\
60-75 \\
\\
\text { Booster: } \\
75\end{array}$ & $\begin{array}{l}\text { Initial: } \\
\text { 10s/5-6w } \\
\\
\text { Booster: } \\
\text { 4s/2-3w }\end{array}$ & $\begin{array}{l}\text { Initial: 10- } \\
12.5 \\
\text { Booster 1: } 5 \\
\text { Booster 2: } 5\end{array}$ & 4 & Lab & $\begin{array}{l}\text { Passive/ } \\
\text { No contact } \\
\text { CG }\end{array}$ & $\begin{array}{l}\text {-TGS showed significant } \\
\text { reduction in processing } \\
\text { speed from baseline to } 5^{\text {th }} \\
\text { year assessment }(d=0.76) \text {. } \\
\text {-TGS that participated in } \\
\text { booster training showed } \\
\text { significantly better } \\
\text { performance on processing } \\
\text { speed at the } 5^{\text {th }} \text { year } \\
\text { assessment compared to } \\
\text { their non-booster } \\
\text { counterparts }(d=0.85) .\end{array}$ & - & $\begin{array}{l}\text {-TGS did not yield any } \\
\text { significant effects on IADL, } \\
\text { Everyday problem solving and } \\
\text { Everyday speed of processing } \\
\text { at the } 5^{\text {th }} \text { year assessments. } \\
\text {-After controlling based line } \\
\text { for age and cognitive function, } \\
\text { TGS that participated in } \\
\text { booster training showed } \\
\text { significant improvement in } \\
\text { performance on Everyday } \\
\text { speed of processing }(d=0.30) \\
\text { compared to their non-booster } \\
\text { counterparts. }\end{array}$ \\
\hline $\begin{array}{l}\text { Ball et al. } \\
\text { (2010) }\end{array}$ & $\begin{array}{l}\text { TGM: } \\
175 \\
\text { TGR: } 145 \\
\text { TGS: } \\
179^{*} \\
\text { CG: } 409 \\
\text { Total (n): } \\
908\end{array}$ & $\begin{array}{l}73.00 \\
(5.59)\end{array}$ & 70 & $10 \mathrm{~s} / 5-6 \mathrm{w}$ & 11.6 & 4 & Lab & $\begin{array}{l}\text { Passive/ } \\
\text { No contact } \\
\text { CG }\end{array}$ & - & - & $\begin{array}{l}\text {-Participants in TGS recorded } \\
35 \text { collisions } 6 \text { years after } \\
\text { baselines and the lowest } \\
\text { number of at-fault crashes, } 18 \\
\text { crashes, compared to other } \\
\text { EGs. } \\
\text {-TGS also reported } \\
\text { significantly lower rates of } \\
\text { MVC's per year of driving } \\
\text { exposure or per person miles } \\
\text { driven. } \\
\text {-Highest number of collision } \\
\text { and at-fault crashes were } \\
\text { recorded among CG. }\end{array}$ \\
\hline $\begin{array}{l}\text { Jones et al. } \\
\text { (2013) }\end{array}$ & $\begin{array}{l}\text { TGM: } \\
296 \\
\text { TGR: } 329 \\
\text { TGS: } \\
\text { 336* } \\
\text { CG: } 698 \\
\text { Total (n): } \\
1659\end{array}$ & $\begin{array}{l}73.80 \\
(6.01)\end{array}$ & $60-75$ & $10 \mathrm{~s} / 5-6 \mathrm{w}$ & $10-12.5$ & 4 & Lab & $\begin{array}{l}\text { Passive/ } \\
\text { No contact } \\
\text { CG }\end{array}$ & $\begin{array}{l}-41.4 \% \text { of initial training } \\
\text { benefits was maintained for } \\
\text { TGS at the 5-year } \\
\text { assessment, with a small to } \\
\text { moderate effect size of }-3.2 \\
\text { T-Score units. } \\
\text {-EGS participants } \\
\text { performed at a level of } \\
\text { about } 7.6 \text { years younger } \\
\text { than CG participants. } \\
\text {-However, age related } \\
\text { change in CG showed } \\
\text { slower decline compared to } \\
\text { those in TGS. }\end{array}$ & - & - \\
\hline
\end{tabular}

\begin{tabular}{|c|c|c|c|c|c|c|c|c|c|c|c|}
\hline \multicolumn{3}{|c|}{ Study Characteristics } & \multicolumn{5}{|c|}{ Intervention } & \multirow{2}{*}{$\begin{array}{c}\begin{array}{c}\text { Control } \\
\text { Condition }\end{array} \\
\text { Type/ } \\
\text { Activity }\end{array}$} & \multicolumn{3}{|c|}{ Cognitive Training Outcomes } \\
\hline Study & $\begin{array}{c}\text { Sample } \\
\text { (n) }\end{array}$ & $\begin{array}{l}\text { Mean } \\
\text { Age } \\
(\mathrm{SD}) \\
\end{array}$ & $\begin{array}{c}\text { Session } \\
\text { Duration } \\
\text { (mins) } \\
\end{array}$ & $\begin{array}{l}\text { Sessions/ } \\
\text { Weeks }\end{array}$ & $\begin{array}{c}\text { Total } \\
\text { Training } \\
\text { (hrs) } \\
\end{array}$ & $\begin{array}{c}\text { No. of } \\
\text { Exercises } \\
\text { Utilized } \\
\end{array}$ & Venue & & Processing Speed & Attention & $\begin{array}{c}\text { Transfer to Other } \\
\text { Cognitive abilities or } \\
\text { Everyday Functions }\end{array}$ \\
\hline Advanced Cc & Trai & Vital and & dependent $\mathrm{E}$ & & & & & & & & \\
\hline $\begin{array}{l}\text { Tennstedt \& } \\
\text { Unverzagt } \\
\text { (2013) }\end{array}$ & $\begin{array}{l}\text { TGM: } \\
703 \\
\text { TGR: } 699 \\
\text { TGS: } \\
702 * \\
\text { CG: } 698\end{array}$ & $\begin{array}{l}73.60 \\
(6.90)\end{array}$ & $\begin{array}{l}\text { Initial: } \\
60-75 \\
\text { Booster: } \\
75\end{array}$ & $\begin{array}{l}\text { Initial: } \\
\text { 10s/5-6w } \\
\text { Booster: } \\
\text { 4s/2-3w }\end{array}$ & $\begin{array}{l}\text { Initial: } 10 \text { - } \\
12.5 \\
\text { Booster 1: } 5 \\
\text { Booster 2: } 5\end{array}$ & 4 & Lab & $\begin{array}{l}\text { Passive/ } \\
\text { No contact } \\
\text { CG }\end{array}$ & $\begin{array}{l}\text {-Largest improvements } \\
\text { were seen in the TGS. } \\
\text {-Training benefits were } \\
\text { greatest immediately after } \\
\text { training, but remained } \\
\text { statistically and practically }\end{array}$ & - & $\begin{array}{l}\text {-TGS Booster showed } \\
\text { improved performance on } \\
\text { Everyday Speed and these } \\
\text { effects were noticeable as } \\
\text { early as at the } 1 \text {-year follow- } \\
\text { up assessment. }\end{array}$ \\
\hline
\end{tabular}


INTERNATIONAL JOURNAL OF ACADEMIC RESEARCH IN BUSINESS AND SOCIAL SCIENCES

Vol. 10, No. 11, 2020, E-ISSN: 2222-6990 (C) 2020 HRMARS

\begin{tabular}{|c|c|c|c|c|c|c|c|c|c|c|c|}
\hline & $\begin{array}{l}\text { Total (n): } \\
2802 \\
\text { Booster } \\
\text { Training } \\
\text { TGM: } \\
\text { 283 } \\
\text { TGR: } 301 \\
\text { TGS: } \\
\text { 295* } \\
\end{array}$ & & & & & & & & $\begin{array}{l}\text { significant at the 5-year } \\
\text { follow-up assessment. } \\
\text {-Booster performances } \\
\text { produced significantly } \\
\text { better performances in the } \\
\text { cognitive ability. }\end{array}$ & & $\begin{array}{l}\text {-TGS participants were } 40 \% \\
\text { less likely to cease driving } 3 \\
\text { years after the 5-year follow- } \\
\text { up assessment. } \\
\text {-At a 6-year period, TGS and } \\
\text { TGR participants showed a } \\
50 \% \text { lower rate of at-fault } \\
\text { motor vehicles collisions than } \\
\text { CG participants. }\end{array}$ \\
\hline $\begin{array}{l}\text { Rebok et al. } \\
\text { (2014) }\end{array}$ & $\begin{array}{l}\text { TGM: } \\
\text { 703 } \\
\text { TGR: } 699 \\
\text { TGS: } \\
\text { 702* } \\
\text { CG: } 698 \\
\text { Total (n): } \\
2802 \\
\end{array}$ & $\begin{array}{l}73.60 \\
(6.90)\end{array}$ & $\begin{array}{l}\text { Initial: } \\
60-75 \\
\\
\text { Booster: } \\
75\end{array}$ & $\begin{array}{l}\text { Initial: } \\
\text { 10s/5-6w } \\
\\
\text { Booster: } \\
\text { 4s/2-3w }\end{array}$ & $\begin{array}{l}\text { Initial: } 10 \text { - } \\
12.5 \\
\text { Booster 1: } 5 \\
\text { Booster 2: } 5\end{array}$ & 4 & Lab & $\begin{array}{l}\text { Passive/ } \\
\text { No contact } \\
\text { CG }\end{array}$ & $\begin{array}{l}\text {-TGS and TGS Booster } \\
\text { showed improvement in } \\
\text { the trained cognitive ability } \\
\text { was retained for } 10 \text { years } \\
\text { with a medium effect size } \\
\text { of } d=0.66 \text { and } d=0.62 \\
\text { respectively. } \\
-70.7 \% \text { of overall TGS } \\
\text { participants were } \\
\text { performing above their } \\
\text { expected cognitive ability } \\
\text { compared to } 48.4 \% \text { in CG. }\end{array}$ & - & $\begin{array}{l}\text {-Overall TGS participants } \\
\text { found it easier to perform } \\
\text { IADL activities at } 10 \text { years } \\
\text { compared to CG with an effect } \\
\text { size of } d=0.36 \text {. } \\
\text {-Although the performance in } \\
\text { IADL activities showed } \\
\text { fluctuation in trained } \\
\text { participants before } 5 \text { years, it } \\
\text { is maintained from } 5 \text { to } 10 \\
\text { years as all participants } \\
\text { continue to decline. } \\
\text {-At } 10 \text { years, } 49.3 \% \text { and } \\
59.5 \% \text { of CG and TGS } \\
\text { participants reported same or } \\
\text { improved level of IADL } \\
\text { difficulty. } \\
\text {-Everyday function was not } \\
\text { impacted by training or } \\
\text { booster training effect. }\end{array}$ \\
\hline $\begin{array}{l}\text { Sharpe et al. } \\
\text { (2014a) }\end{array}$ & $\begin{array}{l}\text { TG: } 692 \\
\text { CG: } 691 \\
\text { Total (n): } \\
1383\end{array}$ & $\begin{array}{l}73.74 \\
(5.92)\end{array}$ & $60-75$ & $10 \mathrm{~s} / 6 \mathrm{w}$ & $10-12.5$ & 4 & Lab & $\begin{array}{l}\text { Passive/ } \\
\text { No contact } \\
\text { CG }\end{array}$ & $\begin{array}{l}\text {-Both the mediation and } \\
\text { direct effect of training on } \\
\text { UFOV improvement was } \\
\text { significant. } \\
\text {-A regression analysis } \\
\text { showed that UFOV scores } \\
\text { improves after training as it } \\
\text { is a significant predictor of } \\
\text { responsiveness. }\end{array}$ & - & - \\
\hline $\begin{array}{l}\text { Sharpe et al. } \\
(2014 b)\end{array}$ & $\begin{array}{l}\text { TG: } 692 \\
\text { CG: } 691 \\
\text { Total (n): } \\
1383\end{array}$ & $\begin{array}{l}73.74 \\
(5.92)\end{array}$ & $60-75$ & $10 \mathrm{~s} / 6 \mathrm{w}$ & $10-12.5$ & 4 & Lab & $\begin{array}{l}\text { Passive/ } \\
\text { No contact } \\
\text { CG }\end{array}$ & $\begin{array}{l}\text {-Regression analysis } \\
\text { showed that TG was a } \\
\text { significant predictor of } \\
\text { responsiveness to training, } \\
\text { indicating performance on } \\
\text { UFOV improves following } \\
\text { training. }\end{array}$ & - & - \\
\hline \multicolumn{12}{|c|}{ Improvement in Memory with Plasticity-based Adaptive Cognitive Training (IMPACT) related studies } \\
\hline $\begin{array}{l}\text { Smith et al. } \\
\text { (2009) }\end{array}$ & $\begin{array}{l}\text { TG:242 } \\
\text { CG: } 245 \\
\text { Total (n): } \\
487 \\
\end{array}$ & $\begin{array}{l}75.29 \\
(6.45)\end{array}$ & 60 & $40 \mathrm{~s} / 8 \mathrm{w}$ & 40 & 6 & Home & $\begin{array}{l}\text { Active/ } \\
\text { Educational } \\
\text { DVD \& Quiz }\end{array}$ & $\begin{array}{l}\text {-Training had a significant } \\
\text { effect on TG }(d=0.87)\end{array}$ & $\begin{array}{l}\text {-TG showed significant } \\
\text { improvement on RBANS } \\
\text { Auditory Memory/Attention } \\
\text { measure }(d=0.23) \\
\end{array}$ & 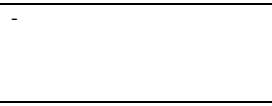 \\
\hline $\begin{array}{l}\text { Zelinski et al. } \\
\text { (2011) }\end{array}$ & $\begin{array}{l}\text { TG: } 245 \\
\text { CG: } 242 \\
\text { Total (n): } \\
487\end{array}$ & $\begin{array}{l}75.29 \\
(6.45)\end{array}$ & 60 & $40 \mathrm{~s} / 8 \mathrm{w}$ & 40 & 6 & Home & $\begin{array}{l}\text { Active/ } \\
\text { Educational } \\
\text { DVD \& Quiz }\end{array}$ & $\begin{array}{l}\text {-TG showed significant } \\
\text { effects on directly trained } \\
\text { processing speed measure } \\
(d=0.80) .\end{array}$ & $\begin{array}{l}\text {-TG no longer showed a } \\
\text { significant effect on primary } \\
\text { measure of RBRANS auditory } \\
\text { memory and attention. }\end{array}$ & $\begin{array}{l}\text {-TG showed significant effects } \\
\text { on overall memory }(d=0.25) \text {. } \\
\text {-TG also showed significant } \\
\text { effects on untrained cognitive } \\
\text { measures of RAVLT ( } d=0.28) \\
\text { and LNS }(d=0.29) \text {. }\end{array}$ \\
\hline $\begin{array}{l}\text { Zelinski et al. } \\
\text { (2014) }\end{array}$ & $\begin{array}{l}\text { TG:245 } \\
\text { CG:242 } \\
\text { Total (n): } \\
487\end{array}$ & $\begin{array}{l}75.29 \\
(6.45)\end{array}$ & 60 & $40 \mathrm{~s} / 8 \mathrm{w}$ & 40 & 6 & Home & $\begin{array}{l}\text { Active/ } \\
\text { Educational } \\
\text { DVD \& Quiz }\end{array}$ & - & - & $\begin{array}{l}\text {-The model that freed the } \\
\text { variances and latent changes } \\
\text { for trained and untrained } \\
\text { outcomes for TG and CG in } \\
\text { each outcome factor score. } \\
\text { Improvements in the training } \\
\text { indicator of speed was } \\
\text { associated with transfer to a } \\
\text { relatively easy list memory } \\
\text { outcome. }\end{array}$ \\
\hline \multicolumn{12}{|c|}{ Independent Researches } \\
\hline $\begin{array}{l}\text { Anderson et al. } \\
\text { (2013) }\end{array}$ & $\begin{array}{l}\text { TG:35 } \\
\text { CG:32 } \\
\text { Total } \\
\text { (n): } 67\end{array}$ & $\begin{array}{l}63.00 \\
(3.70)\end{array}$ & 60 & $5 \mathrm{~s} / 8 \mathrm{w}$ & 40 & 6 & Home & $\begin{array}{l}\text { Active/ } \\
\text { Educational } \\
\text { DVD }\end{array}$ & $\begin{array}{l}\text {-TG showed improvements } \\
\text { in neural timings paired } \\
\text { with perceptual and } \\
\text { cognitive gains in all } \\
\text { measures including } \\
\text { processing speed. } \\
\text { However, similar findings } \\
\text { were not noted for CG. }\end{array}$ & - & - \\
\hline
\end{tabular}

\begin{tabular}{|c|c|c|c|c|c|c|c|c|c|c|c|}
\hline \multicolumn{3}{|c|}{ Study Characteristics } & \multicolumn{5}{|c|}{ Intervention } & \multirow{2}{*}{$\begin{array}{c}\begin{array}{c}\text { Control } \\
\text { Condition }\end{array} \\
\text { Type/ } \\
\text { Activity }\end{array}$} & \multicolumn{3}{|c|}{ Cognitive Training Outcomes } \\
\hline Study & $\begin{array}{c}\text { Sample } \\
\text { (n) }\end{array}$ & $\begin{array}{l}\text { Mean } \\
\text { Age } \\
(\mathrm{SD}) \\
\end{array}$ & $\begin{array}{c}\text { Session } \\
\text { Duration } \\
\text { (mins) }\end{array}$ & $\begin{array}{l}\text { Sessions/ } \\
\text { Weeks }\end{array}$ & $\begin{array}{c}\text { Total } \\
\text { Training } \\
\text { (hrs) }\end{array}$ & $\begin{array}{c}\text { No. of } \\
\text { Exercises } \\
\text { Utilized }\end{array}$ & Venue & & Processing Speed & Attention & $\begin{array}{c}\text { Transfer to Other } \\
\text { Cognitive abilities or } \\
\text { Everyday Functions }\end{array}$ \\
\hline \multicolumn{12}{|c|}{ Independent Researches } \\
\hline $\begin{array}{l}\text { Anderson et al. } \\
\text { (2014) }\end{array}$ & $\begin{array}{l}\text { TG: } 30 \\
\text { CG: } 32 \\
\text { Total (n): } \\
62\end{array}$ & $\begin{array}{l}62.97 \\
(3.80)\end{array}$ & 60 & $5 \mathrm{~s} / 8 \mathrm{w}$ & 40 & 6 & Home & $\begin{array}{l}\text { Active/ } \\
\text { Educational } \\
\text { DVD }\end{array}$ & $\begin{array}{l}\text {-TG maintained } \\
\text { improvements in speed of } \\
\text { processing outcome at } 6- \\
\text { months follow-up but not } \\
\text { CG. } \\
\text {-TG showed improvement } \\
\text { in speed of processing } \\
\text { maintained from pre- }\end{array}$ & - & - \\
\hline
\end{tabular}


INTERNATIONAL JOURNAL OF ACADEMIC RESEARCH IN BUSINESS AND SOCIAL SCIENCES

Vol. 10, No. 11, 2020, E-ISSN: 2222-6990 (C) 2020 HRMARS

\begin{tabular}{|c|c|c|c|c|c|c|c|c|c|c|c|}
\hline & & & & & & & & & $\begin{array}{l}\text { testing to 6-months follow- } \\
\text { ups. Such changes was not } \\
\text { present in the CG. }\end{array}$ & & \\
\hline $\begin{array}{l}\text { Belchior et al. } \\
\text { (2013) }\end{array}$ & $\begin{array}{l}\text { TGV1: } 14 \\
\text { TG: } 16 \\
\text { PCT: } 15 \\
\text { CG: } 13 \\
\text { Total (n): } \\
58\end{array}$ & $\begin{array}{l}74.50 \\
(6.70)\end{array}$ & 90 & $6 \mathrm{~s} / 2-3 \mathrm{w}$ & 9 & 4 & Lab & $\begin{array}{l}\text { Passive/ } \\
\text { No contact } \\
\text { CG }\end{array}$ & $\begin{array}{l}\text {-TG produced not } \\
\text { significant but marginally } \\
\text { better performance on } \\
\text { UFOV test compared to } \\
\text { EGV1 and PCT. }\end{array}$ & $\begin{array}{l}\text {-TG participants performed } \\
\text { slightly better on selective } \\
\text { attention task at post-test } \\
\text { compared to pre-test. This } \\
\text { trend was followed by PCT } \\
\text { and EVG1 participants } \\
\text { respectively. } \\
\text {-CG participants performed } \\
\text { slower at post-test compared } \\
\text { to pre-test. }\end{array}$ & - \\
\hline $\begin{array}{l}\text { Belchior et al. } \\
\text { (2019) }\end{array}$ & $\begin{array}{l}\text { TGC: } 19 \\
\text { TGV: } 17 \\
\text { CG: } 18 \\
\text { Total }(\mathrm{n}): \\
54\end{array}$ & $\begin{array}{l}73.20 \\
(5.50)\end{array}$ & 60 & $60 \mathrm{~s} / 12 \mathrm{w}$ & 60 & 5 & Home & $\begin{array}{l}\text { Passive/ } \\
\text { No contact } \\
\text { CG }\end{array}$ & $\begin{array}{l}\text {-TGC performed better } \\
\text { than TGV on two UFOV } \\
\text { measures immediately after } \\
\text { training }(\mathrm{ES}=0.5,0.7) \text { and } \\
\text { at } 3 \text {-month post follow-ups } \\
(\mathrm{ES}=0.6,0.8) .\end{array}$ & $\begin{array}{l}\text {-Performance on attention } \\
\text { domains, specifically visual } \\
\text { attention, (in addition to those } \\
\text { measure by the UFOV } \\
\text { subsets) are as follows. } \\
\text {-TGC performed better than } \\
\text { TGV on multiple object } \\
\text { tracking (ES = 1.6) but not CG } \\
\text { immediately after training. } \\
\text { However, these differences } \\
\text { disappeared by the 3-months } \\
\text { follow-ups. } \\
\text {-TGV performed better than } \\
\text { EGC on attentional blink } \\
\text { immediately after training (ES } \\
=1.1 \text { ). However, at 3-months } \\
\text { follow-ups, TGC continued to } \\
\text { improve, TGV showed some } \\
\text { declines and both training } \\
\text { groups were better than } \\
\text { control (ES = 0.9). }\end{array}$ & $\begin{array}{l}\text {-At the immediate post-test } \\
\text { level, TGC and TGC did not } \\
\text { significantly differ from CG } \\
\text { on TIADLs performance. } \\
\text {-By the } 3 \text {-months follow-ups, } \\
\text { both TGC and TGV showed } \\
\text { improvement and performed } \\
\text { better than CG on TIADLs } \\
\text { (ES }=0.8 \text { ). However, no } \\
\text { difference was observed on } \\
\text { this performance between } \\
\text { TGC and TGV. }\end{array}$ \\
\hline $\begin{array}{l}\text { Edwards et al. } \\
\text { (2013a) }\end{array}$ & $\begin{array}{l}\text { TG: } 27 \\
\text { CG: } 33 \\
\text { Total (n): } \\
60\end{array}$ & $\begin{array}{l}73.99 \\
(7.48)\end{array}$ & 60 & $\begin{array}{l}20 \mathrm{~s} / 10- \\
12 \mathrm{w}\end{array}$ & 20 & 5 & Lab & $\begin{array}{l}\text { Passive/ } \\
\text { No contact } \\
\text { CG** }\end{array}$ & $\begin{array}{l}\text {-TG showed significantly } \\
\text { greater improvements in } \\
\text { UFOV scores from pre-to- } \\
\text { post training compared to } \\
\text { CG. }\end{array}$ & - & - \\
\hline $\begin{array}{l}\text { Eramudugolla } \\
\text { et al. (2017) }\end{array}$ & $\begin{array}{l}\text { TG: } 24 \\
\text { CG: } 24 \\
\text { Total (n): } \\
48\end{array}$ & $\begin{array}{l}71.60 \\
(4.07)\end{array}$ & $\begin{array}{l}\text { Not } \\
\text { provided } \\
\text { (Particip- } \\
\text { ants to } \\
\text { train for } \\
120 \text { mins } \\
\text { per week) }\end{array}$ & $2 \mathrm{~s} / 5 \mathrm{w}$ & 10 & 1 & Home & $\begin{array}{l}\text { Passive/ } \\
\text { No contact } \\
\text { CG }\end{array}$ & $\begin{array}{l}\text {-TG performed better than } \\
\text { CG on UFOV at follow-up, } \\
\text { showing a moderate effect } \\
\text { size and explaining } 20 \% \text { of } \\
\text { variance in scores. }\end{array}$ & $\begin{array}{l}\text {-No transfer effects were } \\
\text { observed from TG to Trail } \\
\text { Making Test B (a measure of } \\
\text { cognitive flexibility and } \\
\text { attentional shifting). }\end{array}$ & $\begin{array}{l}\text {-TG also reported near } \\
\text { transfers to the Maze Test and } \\
\text { Hazard Perception Test, in } \\
\text { showing significant reduction } \\
\text { in completion speed and } \\
\text { significant increase in } \\
\text { response time for detecting } \\
\text { hazards respectively. }\end{array}$ \\
\hline $\begin{array}{l}\text { Faust et al. } \\
(2020)\end{array}$ & $\begin{array}{l}\text { TGVs } 39 \\
\text { TGA: } 38 \\
\text { TGVA: } \\
37 \\
\text { CG: } 37 \\
\text { Total (n): } \\
151\end{array}$ & $\begin{array}{l}69.88 \\
(5.86)\end{array}$ & 40 & $\begin{array}{l}30 \mathrm{~s}-40 \mathrm{~s} / \\
8-10 \mathrm{w}\end{array}$ & 15 & $\begin{array}{l}\text { EGV: } 5 \\
\text { EGA: } 6 \\
\text { EGVA: } \\
\text { Alternate } \\
\text { between } \\
11 \\
\text { exercises }\end{array}$ & Lab & $\begin{array}{l}\text { Passive/ } \\
\text { No contact } \\
\text { CG } * *\end{array}$ & $\begin{array}{l}\text {-TGV showed significant } \\
\text { pre-post changes for all } \\
\text { outcome measures except } \\
\text { verbal index } 2 \text { and } \\
\text { processing speed. } \\
\text {-TGV also showed transfer } \\
\text { effects for RBRANS Total } \\
\text { ( } d=0.42 \text { and visual } \\
\text { processing }(d=0.35) \text {. } \\
\text {-TGA showed significant } \\
\text { pre-post changes for global } \\
\text { cognition and processing } \\
\text { speed. } \\
\text {-TGVA did not show } \\
\text { significant pre-post } \\
\text { outcome measure changes. } \\
\text {-CG did not show } \\
\text { significant pre-post } \\
\text { outcome measure changes, } \\
\text { except for improvements in } \\
\text { processing speed. } \\
\text {-Results showed a lack of } \\
\text { evidence of synergistic } \\
\text { combination of visual and } \\
\text { auditory exercises. }\end{array}$ & - & $\begin{array}{l}\text {-TGV showed transfer effect } \\
\text { to working memory }(d=0.45) \text {. } \\
\text { TGA showed no significant } \\
\text { transfer effects. }\end{array}$ \\
\hline $\begin{array}{l}\text { Mishra et al. } \\
\text { (2015) }\end{array}$ & $\begin{array}{l}\text { TG: } 14 \\
\text { CG: } 14 \\
\text { Total (n): } \\
28\end{array}$ & $\begin{array}{l}71.93 \\
(7.53)\end{array}$ & 40 & $\begin{array}{l}3 s-5 s / \\
3 w-5 w\end{array}$ & 10 & 1 & $\begin{array}{l}\text { Lab or } \\
\text { Home }\end{array}$ & $\begin{array}{l}\text { Passive/ } \\
\text { No contact } \\
\text { CG }\end{array}$ & $\begin{array}{l}\text {-Significant improvements } \\
\text { were only seen in the TG } \\
\text { vs. CG for the ds } 50 \text { and ds } \\
100 \text { stimuli and no others. }\end{array}$ & - & - \\
\hline
\end{tabular}

\begin{tabular}{|c|c|c|c|c|c|c|c|c|c|c|c|}
\hline \multicolumn{3}{|c|}{ Study Characteristics } & \multicolumn{5}{|c|}{ Intervention } & $\begin{array}{c}\text { Control } \\
\text { Condition }\end{array}$ & \multicolumn{3}{|c|}{ Cognitive Training Outcomes } \\
\hline Study & $\begin{array}{c}\text { Sample } \\
\text { (n) }\end{array}$ & $\begin{array}{l}\text { Mean } \\
\text { Age } \\
(\mathrm{SD})\end{array}$ & $\begin{array}{c}\text { Session } \\
\text { Duration } \\
\text { (mins) }\end{array}$ & $\begin{array}{c}\text { Sessions/ } \\
\text { Weeks }\end{array}$ & $\begin{array}{c}\text { Total } \\
\text { Training } \\
\text { (hrs) }\end{array}$ & $\begin{array}{c}\text { No. of } \\
\text { Exercises } \\
\text { Utilized }\end{array}$ & Venue & $\begin{array}{c}\text { Type/ } \\
\text { Activity }\end{array}$ & Processing Speed & Attention & $\begin{array}{c}\text { Transfer to Other } \\
\text { Cognitive abilities or } \\
\text { Everyday Functions }\end{array}$ \\
\hline \multicolumn{12}{|c|}{ Independent Researches } \\
\hline $\begin{array}{l}\text { O'Brien et al. } \\
\text { (2013) }\end{array}$ & $\begin{array}{l}\text { TG:11 } \\
\text { CG:11 } \\
\text { Total (n): } \\
22\end{array}$ & $\begin{array}{l}71.86 \\
(5.06)\end{array}$ & $\begin{array}{l}70 \\
\text { (includin } \\
\text { g breaks) }\end{array}$ & $20 \mathrm{~s} / 10 \mathrm{w}$ & $\begin{array}{l}20 \text { (min } \\
16 \text { hrs to be } \\
\text { completed) }\end{array}$ & 5 & Lab & $\begin{array}{l}\text { Passive/ } \\
\text { No contact } \\
\text { CG. *** }\end{array}$ & - & $\begin{array}{l}\text {-TG showed significant } \\
\text { increase in amplitude of } \\
\text { electrophysiological measures } \\
\text { reflecting the allocation of } \\
\text { attention through visual. space } \\
\text { during visual search } \\
\text {-TG also showed significant } \\
\text { increase in attentional capacity } \\
\text { after training. } \\
\text {-TG participants which did not } \\
\text { perform at ceiling levels } \\
\text { showed enhanced accuracy on } \\
\text { a visual search task. }\end{array}$ & - \\
\hline
\end{tabular}


INTERNATIONAL JOURNAL OF ACADEMIC RESEARCH IN BUSINESS AND SOCIAL SCIENCES

Vol. 10, No. 11, 2020, E-ISSN: 2222-6990 (C) 2020 HRMARS

\begin{tabular}{|c|c|c|c|c|c|c|c|c|c|c|c|}
\hline & & & & & & & & & & $\begin{array}{l}\text {-CG did not show significant } \\
\text { increase across any of the } \\
\text { above mentioned measures. }\end{array}$ & \\
\hline $\begin{array}{l}\text { Smith et al. } \\
\text { (2018) }\end{array}$ & $\begin{array}{l}\text { TG: } 173 \\
\text { CG: } 178 \\
\text { Total (n): } \\
351\end{array}$ & $\begin{array}{l}81.00 \\
(-)\end{array}$ & $50-60$ & $\begin{array}{l}\text { Initial: } \\
1-2 \mathrm{~s} / 6 \mathrm{w} \\
\\
\text { Booster: } \\
\text { Informati } \\
\text { on not } \\
\text { provided }\end{array}$ & $\begin{array}{l}\text { Initial: } 10 \\
\text { Booster1:4 } \\
\text { Booster2:4 }\end{array}$ & 1 & Home & $\begin{array}{l}\text { Active/ } \\
\text { Crossword } \\
\text { Puzzles }\end{array}$ & $\begin{array}{l}\text {-TG showed bigger } \\
\text { reductions in UFOV scores } \\
\text { at post-training }(d=0.25) \text {, } \\
\text { 6-months follow-up } \\
(d=0.40) \text { and } 12-\text {-months } \\
\text { follow-up }(d=0.27) \\
\text { compared CG. } \\
\text {-The estimated marginal } \\
\text { means of achieving } \geq 0.5 \\
\text { SD in UOFV s sores for EG } \\
\text { vs. CG groups are } 35.0 \% \\
\text { vs. } 25.2 \%, 39.1 \% \text { vs. } \\
28.7 \% \text {, and } 40.0 \% \text { vs. } \\
25.5 \% \% \text { at post-training, six } \\
\text { months, and twelve } \\
\text { months. }\end{array}$ & - & 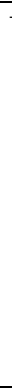 \\
\hline
\end{tabular}

Key; $\quad *$ Only results from that particular training group was analyzed for the purpose of this research.

** No contact control group were wait-list control groups and were given an opportunity to experience training after post-training assessments were over.

Abbreviations: $\mathrm{TG}=$ Training Group; $\mathrm{CG}=$ Control Group; TGM = Training Group Memory; EGR = Training Group Reasoning; EGS = Training Group SOP; EGC - Training Group Cognitive SOP; $E G V=$ Training Group Videogame; EGVs = Training Group Visual; EGA = Training Group Auditory; EGVA = Training Group Visual and Auditory; $A C=$ Active Control; NCC $=$ No-Contact Control; EGV1 = Training Group Videogame 1 (Medal of Honour); PCT = Placebo Control Training (Tetris). 